\title{
Caminhar na Trilha Norte-Sul: infraestrutura verde entre o Parque da Água Branca e o Horto Florestal em São Paulo [SP]
}

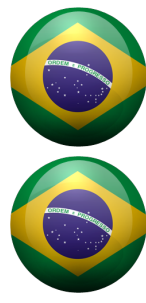

\section{Cíntia Miua Maruyama}

Arquiteta e Urbanista pela FAU USP, Mestre em Engenharia Urbana pela UEM-PR, Professora Assistente da Universidade Federal do Paraná, no Centro de Estudos do Mar. Pontal do Paraná [PR] Brasil. <cintiamaruyama@ufpr.br>.

\section{Maria de Assunção Ribeiro Franco}

Arquiteta e Urbanista, Doutora, Livre Docente, Professora Titular da FAU USP - Departamento de Projeto. São Paulo [SP] Brasil <mariafranco@usp.br>.

\section{Resumo}

A infraestrutura verde propõe uma visão alternativa para as cidades com urbanização cinza tradicional. Dentre os diversos benefícios propiciados por esta abordagem estão a amenização dos efeitos das ilhas de calor urbanas, o manejo sustentável das águas da chuva e a melhoria dos transportes não motorizados. Por outro lado, calçadas dotadas de arborização e com dimensões adequadas fornecem condições de conforto urbano ao pedestre. 0 presente artigo faz parte do Projeto FAPESP № 2015/10597-0 Infraestrutura Verde para a Resiliência Urbana às Mudanças Climáticas da Cidade de São Paulo, sob responsabilidade de Maria de Assunção Ribeiro Franco. Neste artigo, investiga-se a suposição de que bons passeios públicos possam estimular a prática da caminhada, pois exercícios físicos regulares são importantes para a saúde da população e, dentre as diversas modalidades possíveis, a caminhada é uma forma econômica de se exercitar e ao alcance da maioria das pessoas. Os objetivos deste trabalho foram: analisar as condições das calçadas e os hábitos relativos ao hábito da caminhada, assim como os locais onde isto é efetivado; os costumes referentes ao uso das praças e parques; avaliar os efeitos das ilhas de calor no trecho em estudo. A metodologia envolveu a análise da adequação física e da arborização urbana das calçadas, num trecho entre o Parque da Água Branca e a região do Horto Florestal em São Paulo [SP]. Por meio da aplicação de questionários foi verificada a percepção dos usuários em relação aos assuntos mencionados. De forma geral, os resultados da pesquisa com usuários indicaram que 35\% dos entrevistados não se sente bem no ato de caminhar e a principal alegação apresentada foi a inadequação das calçadas. Por outro lado, 80\% dos usuários sinalizaram haver mais disposição para caminhar se houver mais arborização nas vias. Os resultados da pesquisa confirmaram a hipótese em determinados trechos e há a necessidade de realizar melhorias a fim de adequar as calçadas e a arborização para incentivo das caminhadas. Também foi detectada a necessidade de aumentar a segurança das praças da área de estudo, bem como criar mais opções de lazer e esporte para a população. Por fim, foram observadas ilhas de calor na área de estudo, as quais coincidiram com os locais onde a arborização foi avaliada como crítica. Possibilidades de mitigação dos efeitos destas ilhas de calor dentro de uma infraestrutura verde incluem plantio maciço de árvores e outros estratos de vegetação, adoção de tetos verdes e pavimentos brandos nas vias.

\section{Palavras-chave}

Infraestrutura verde. Caminhada. Pavimentos brandos. Parques. Ilhas de calor urbanas.

\section{Walking on the North-South Trail: green infrastructure between Parque da Agua Branca and Horto Florestal in Sao Paulo [SP]}

\begin{abstract}
Green infrastructure proposes an alternative to gray traditional urbanization. Among the several benefits provided by this approach are the mitigation of the effects of urban heat islands, the sustainable management of rainwater and the improvement of non-motorized transport. On the other hand, sidewalks with good arborization and adequate dimensions can provide the conditions for urban comfort. This article is part of Project FAPESP No. 2015 / 10597-0 Green Infrastructure for the Urban Resilience to Climate Change of the City of São Paulo, under the responsibility of Maria de Assunção Ribeiro Franco. This article studies the hypothesis that good quality sidewalks situated in public spaces can stimulate the practice of walking, because practice of regular physical activity is important for the maintenance of the population health. Among the several possible modalities, walking is an economical way to exercise and within the reach of most people. Purposes of this study are to analyze the conditions of the sidewalks and the habits related to the practice of walking, as well as to identify the places where this practice is carried out and the customs referring to the use of squares and parks. Another purpose is to analyze the temperature of the area in relation to the urban heat islands. The applied methodology was based on collecting data of the physical conditions of both, the sidewalks and their vegetation, in 04 points located in a stretch between the Água Branca park and Horto Florestal region in São Paulo / SP, as well as through the application of a survey investigating users opinions regarding the mentioned topic. As an overview of the interviews, 35\% of respondents said that they did not felt good about walking and the main reason was the inadequacy of the sidewalk conditions. On the other hand, $80 \%$ of users indicated that
\end{abstract}


there is more willingness to walk if there is more afforestation on the streets. With the results of this research it was concluded that, for the studied area, the hypothesis was confirmed in parts of the study area and the quality of the sidewalks must be improved mainly by increasing the number of trees and, so encouraging people to the practice of walking. It was also observed the need to increase security within the studied areas plazas, as well the need to increase the options for leisure and sports. At last, urban heat islands were observed in the study area, especially where the arborization was deficient. Possibilities to mitigate the effects of these heat islands within a green infrastructure include massive planting of trees and other types of vegetation, adoption of green ceilings and cool pavements on the streets.

\section{Keywords}

Green infrastructure. Walking. Cool pavement. Parks. Urban heat islands.

\section{Introdução}

A infraestrutura verde - IV encara a paisagem como multifuncional e alia a este conceito a visão dos espaços naturais em um sistema (Moura, 2013). Ela também defende que a paisagem das ruas, praças e edificações integrem tecnologias que tornem possível o aproveitamento de benefícios e serviços ecológicos que tais espaços e ambientes podem proporcionar (Ahern; Pellegrino \& Becker 2012; Moura, 2013). São exemplos destes serviços ecológicos: redução dos efeitos das ilhas de calor urbanas, manejo sustentável das águas da chuva, além da melhoria dos transportes não motorizados, como a caminhada, entre outros. A caminhada é acessível a uma grande parte da população. Assim o investimento em municípios convidativos para o andar a pé e a existência de condições adequadas para tais práticas são excelentes ações em prol da melhoria da saúde pública. A prática constante de exercícios físicos deveria fazer parte da rotina das pessoas, assim como os bons hábitos de higiene e cuidado pessoal. São diversos os estudos correlacionando a falta de atividade física com diversos problemas de doenças mais prevalente na população (Matsudo et al., 2002; Chomistek et al., 2013; Kubota et al., 2017) apontando para a necessidade do exercício físico regular.

Dentre os fatores que favorecem o exercício por caminhada destacam-se: existência de calçadas adequadas e condições de conforto ambiental. Neste último aspecto a arborização urbana colabora proporcionando sombreamento e aliviando a sensação de calor, fato importante considerando que grande parte do país tem o clima classificado como quente. Dentre os diversos benefícios da arborização urbana citamos: maior qualidade estética e prover a sensação de aproximação do ser humano com a natureza, auxiliando a tornar os ambientes visualmente menos áridos. Desta forma a hipótese do presente artigo é que a existência de calçadas adequadas e com arborização são fatores de estimulo à prática do caminhar.

Em Campina Grande [PB] (Araújo; Araújo; Araújo, 2010) e em Pires do Rio [GO] (Rodrigues, Malafaia, Queiroz, \& Rodrigues, 2010) foi analisada a visão dos moradores com relação à arborização urbana, os aspectos verificados foram referentes à preservação das espécies, benefícios e importância das árvores, manejo, entre outros. Em São Carlos [SP] foi conduzida uma investigação sobre os aspectos ambientais e as motivações do hábito de caminhar, mas a arborização urbana não estava entre os aspectos analisados (Schützer, 2011). Na região da Zona Norte de São Paulo [SP] foi avaliada a percepção da caminhabilidade pela percepção do pedestre, qualidade ambiental e urbana e novamente a arborização urbana não estava entre os itens da pesquisa (Marques \& Batistela, 2016).

Observou-se a carência de trabalhos avaliando tanto a percepção dos usuários relativa à caminhada e sua visão da arborização no meio urbano em um texto único, os estudos existentes mencionam a hábito de caminhar ou avaliam a arborização de forma separada. Assim os objetivos deste trabalho foram avaliar a caminhada, a arborização urbana; os parques e praças sob a análise dos pesquisadores e relativa à percepção do usuário; avaliar as ilhas de calor presentes no trecho em estudo. Tal pesquisa foi conduzida num trecho entre a área do Parque da Água Branca até a região do Parque Horto Florestal em São Paulo [SP].

\section{Revisão de literatura}

Neste tópico serão apresentados conceitos de vegetação urbana, infraestrutura verde para mitigação dos efeitos das ilhas de calor urbanas, calçadas com relação às legislações. 
Aliar estudos de percepção ambiental ao planejamento urbano é uma forma de aproximar o olhar daquele que planeja com a percepção do usuário. Incluir tal matéria pode auxiliar os projetos ligados ao ambiente urbano a terem maior qualidade ambiental para que os ambientes atendam mais adequadamente às expectativas da população.

Por outro lado, é essencial a existência de espaços verdes no meio urbano, estes colaboram para a qualidade do ambiente e da vida da população (Costa \& Colesanti, 2011).

De modo geral cidades enfrentam uma série de problemas que afetam tanto a saúde física como a mental dos seus habitantes, tais como degradação do ar e da água, ruídos excessivos, entre outros.

0 verde é uma opção para minimizar tais fatores negativos, em especial nos espaços públicos (Costa, 2011) tal fato vem sendo objeto de diversos estudos (Nucci, 2008; Oliveira, 1996; Cicea; Pirlogea, 2011). Nestes trabalhos se enfatizou a investigação de benefícios advindos pelas áreas verdes à população, tendo como premissa que estas áreas exercem importante papel na melhoria da qualidade ambiental e de vida da população, ao desenvolver funções ecológicas, sociais e de lazer (Costa, 2011). Funções estas essenciais no sentido de proverem bem-estar aos cidadãos em seu relacionamento com o meio ambiente.

Ainda no contexto da vegetação urbana, as árvores desempenham papel essencial, pois devido ao seu volume de folhas das copas, seu porte e outros elementos, fornecem influência positiva no meio ambiente muito mais significante do que plantas menores, como as rasteiras e arbustivas. Desta forma, as árvores fornecem inúmeros serviços ecológicos, tais como oferecimento de habitat para diversas espécies e assim colaborar para manutenção da biodiversidade, captura de gases que provocam o efeito estufa, auxilio na minimização dos efeitos das ilhas de calor, melhoria dos microclimas locais e provisão de conforto climático aos pedestres, dentre outros (Herzog, 2010; Mascaró; Mascaró, 2005).

Os benefícios da vegetação na mitigação dos efeitos da ilhas de calor urbanas têm sido estudada por diversos trabalhos, tanto brasileiros (Rocha; Souza; Castilho, 2011; Alves; Biudes, 2012) quanto estrangeiros (Gülten, A. et al., 2016; Edmondson, et al., 2016; Liveslay; McPherson; Calfapietra, 2016).

O benefício do sombreamento propiciado pelo dossel arbóreo também é importante ${ }^{1}$, principalmente se considerarmos que a área de estudo do presente estudo sofre com problemas das Ilhas de Calor - IC. As IC são observadas há tempos em pontos urbanos e suburbanos, áreas como "oasis" invertidos, onde há regiões mais quentes do que outras adjacentes (Gartland, 2001). Em grande parte do globo as IC são encaradas como danosas, pois levam a consumo suplementar para resfriamento de ambientes, veículos, etc. (Lopes, 2006).

Para mitigar os efeitos das IC, dentro do conceito de infraestrutura verde, há possibilidade de três práticas: adoção de coberturas verdes, pavimentos brandos e plantio de árvores e vegetação (Gartland, 2010; Rosenfeld et al., 1998). Pavimentos são brandos (cool pavement) quando há incremento em sua refletância solar (com camadas reflexivas por exemplo) ou com aumento de sua capacidade de armazenamento e evaporação de água - pavimento permeável (Gartland, 2010). A temperatura dos pavimentos brandos pode ser reduzida em $15^{\circ} \mathrm{C}$ ou mais, mantendo o pico das temperaturas abaixo de $50^{\circ} \mathrm{C}$. Isto é bastante, se considerarmos que os pavimentos mais quentes chegam até $65^{\circ} \mathrm{C}$ ou mais no verão (Ibidem). Experimentos de Rosenfeld (1998) demostraram que coberturas com tons próximos de branco e o uso de pavimentos de tons claros podem reduzir a temperatura do ar em $1,5^{\circ} \mathrm{C}$. Se forem também plantadas árvores maciçamente pode-se chegar à redução de $3^{\circ} \mathrm{C}$ na temperatura ambiente. No caso o cenário supunha o uso de pavimento de concreto. Num outro cenário, mais realista que não implicaria em remover imensa quantidade de asfalto já existente nas vias, há a alternativa de adoção de pinturas reflexivas nos pavimentos, para obter o mesmo benefício de redução de calor. Contudo ainda são necessários mais estudos sobre o efeito das pinturas reflexivas em pavimentos no ambiente, principalmente a respeito das consequências do incremento da reflexão do calor do pavimento sobre os pedestres (Pisello, 2017).

1 A evapotranspiração das árvores também é importante para ajudar a diminuir os efeitos das IC, pois durante este processo há a retirada de calor do ambiente.

(C) Labor \& Engenho, Campinas [SP] Brasil, v.11, n.3, p.355-373, jul./set. 2017. 
Com relação às calçadas, a legislação federal prevê normas gerais e critérios para a promoção da acessibilidade de pessoas com deficiência ou mobilidade reduzida, estabelecidos pelo Decreto 5296/2004 (Brasil, 2004). Este texto estabelece que a concepção e execução de projeto arquitetônico e urbanístico devem atender as premissas do Desenho Universal, tendo como referência as normas da ABNT, legislação específica e as regras do Decreto (Ibidem). Já a legislação municipal de São Paulo estabelece a padronização dos passeios públicos pelo Decreto Municipal 45.904/2005 (São Paulo, 2005). Dentre as diversas providências previstas neste texto está a largura mínima de faixa livre de $1,20 \mathrm{~m}$ e a recomendação dos materiais do pavimento da calçada em concreto, ladrilho hidráulico ou intertravado. Também é interessante haver a preocupação ecológica, quando o texto sugere que se possível se aplique piso permeável, o qual deve fazer parte do sistema drenante que encaminhe as águas para o sistema de drenagem pública.

\section{Método}

Quanto à delimitação da área de estudo, está localizada no município de São Paulo [SP], num trecho que delimita um retângulo (Figura 1), denominado "Trilha Norte-Sul". Nesta área está sendo desenvolvida uma pesquisa intitulada: "Infraestrutura verde para a resiliência urbana às mudanças climáticas na cidade de São Paulo" e está cadastrado como Projeto FAPESP no 2015/10597-0, sob responsabilidade de Maria de Assunção Ribeiro Franco. Na "Trilha Norte-Sul" foi definida uma buffer zone de $500 \mathrm{~m}$ teórica para o desenvolvimento dos estudos (Figura 1). 0 presente artigo trata de parte desta pesquisa, e avaliou os espaços da caminhada, a arborização urbana, os parques, praças e ilhas de calor em parte desta "Trilha", na região entre o Parque da Água Branca até a área do Horto Florestal.

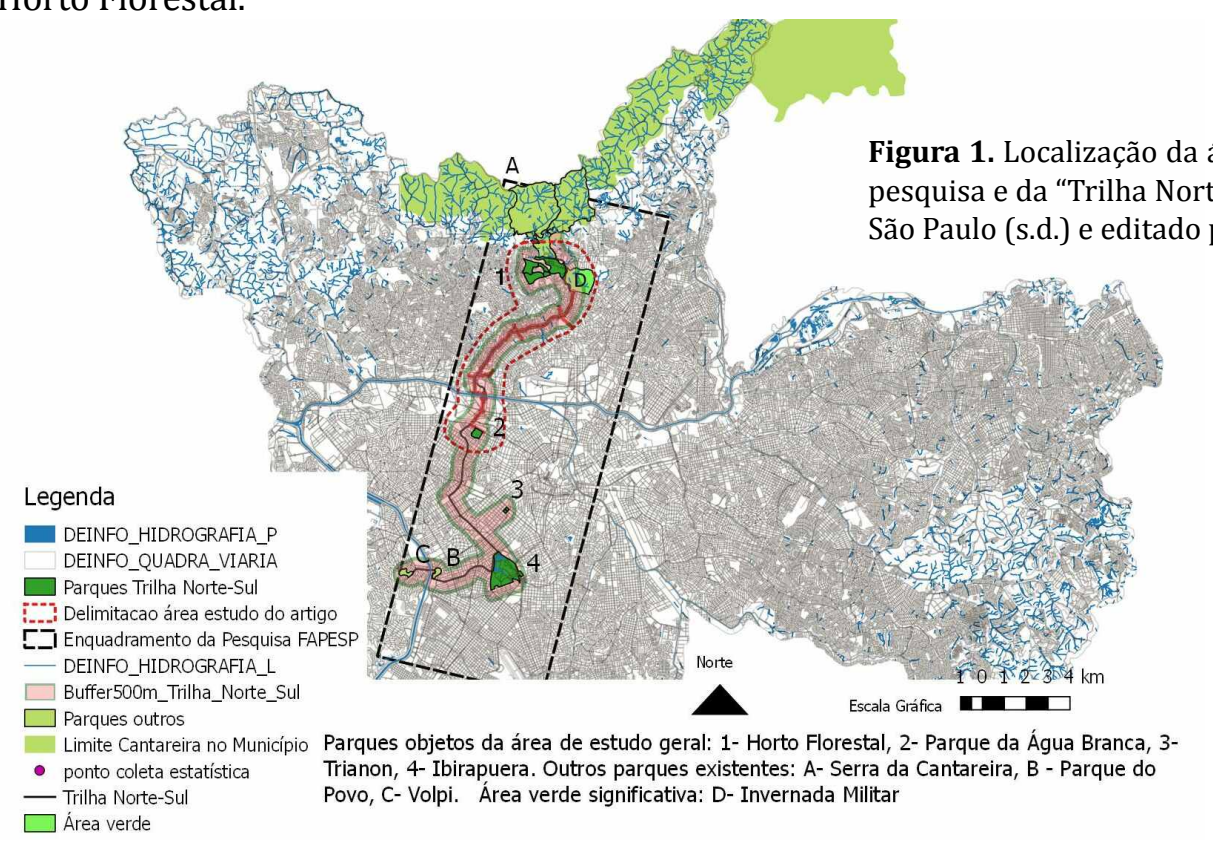

A metodologia abrangeu verificação da adequação da área de estudo e levantamento estatístico com avaliação da visão dos usuários com relação às condições da arborização urbana, dos espaços para caminhada, praças e parques. A pesquisa com usuários abordou os seguintes procedimentos: foram determinados quatro pontos para coleta de questionários, tais pontos foram lançados no software Quantun GIS, em uma em uma buffer zone delimitada pela região do Parque da Água Branca e até a região do Horto Florestal. Então foram elaborados mapas, com estes pontos e os principais espaços verdes da região como o Parque da Água Branca, Horto Florestal, a Invernada da Polícia Militar de São Paulo, e a grande mancha verde formada pela Serra da Cantareira.

O tipo de levantamento estatístico adotado foi o descritivo (Gil, 1999), a seguir foi construído um questionário semiestruturado para definição das variáveis com o tema proposto. A determinação do universo total das entrevistas da área de estudo foi estabelecida com o Quantun GIS - QGIS, a partir de shapefiles dos setores censitários da pesquisa censo do IBGE de 2010, obtidos junto ao Mapa Digital - MDC da Prefeitura de São Paulo (Prefeitura de São Paulo, s/d). Tais dados foram carregados no QGIS juntamente com a buffer zone estabelecida para o presente trabalho, assim foi determinada a população de 283.255 pessoas. 
A definição do tamanho da amostra (aleatória simples) foi obtida por cálculos estatísticos, com o uso da margem de erro de 6,89\%. Então lançamos a população e a margem de erro na equação para cálculo amostral (Santos, s/d). Os resultados indicaram a necessidade de uma amostra mínima de 200 entrevistas, então foram aplicadas 210 para uma margem mais segura de erro. A adequação dos espaços para caminhada, como calçadas e arborização urbana, foram os itens analisados na área de estudo, cujos critérios serão descritos a seguir.

Com relação à análise das calçadas, adotaram-se critérios qualitativos fundamentados na experiência de visita de campo feita pelos pesquisadores, bem como pela aplicação de entrevistas com usuários. Quanto aos critérios adotados para a análise pelos pesquisadores, estes consideraram os seguintes itens: largura, existência de degraus, revestimento e manutenção das calçadas.

Com relação ao item largura de calçadas, Prinz (1980) indica a largura mínima para ruas locais de $1,50 \mathrm{~m}$, sendo a ideal de $3,0 \mathrm{~m}$ e se houver mobiliários urbanos como paradas de ônibus, $3,50 \mathrm{~m}$. A NBR 9050 (2004) estabelece o passeio com medida mínima de $1,20 \mathrm{~m}$ e a ideal de $1,50 \mathrm{~m}$. A partir destas considerações adotou-se a largura mínima para passeio de 1,50m.

Prinz (1980) recomenda que nos locais com algo tráfego veicular seja estabelecido afastamento mínimo entre o pedestre e automotores de $2,0 \mathrm{~m}$ quando for feito por faixa vegetada (Figura 3). Como opção para espaços muito limitados, é possível inserir tal segregação por elementos físicos, como obstáculos de pedra ou concreto dotados de 1,0m de largura (Ibidem). Tais observações determinam a largura mínima de calçada em ruas coletoras e arteriais de 3,50m, quando esta possui faixa de vegetação; $2,50 \mathrm{~m}$ com obstáculos físicos. Tal largura de 2,50m de calçada comporta o plantio de árvores (Mascaró, 2005).

Analisando os critérios descritos anteriormente numa infraestrutura verde, a faixa verde da calçada deve comportar jardim de chuva ou biovaleta, dependendo das condições geotécnicas de capacidade de infiltração do solo. 0 jardim de chuva (Figura 2) é localizado em cotas mais baixas, recebe as águas da chuva de superficies impermeáveis e coberturas adjacentes e promove sua lenta infiltração no solo. A análise do solo nos dirá se a água poderá ser totalmente infiltrada ou parte lançada para extravasores dimensionados para o pico dos fluxos de concentração das maiores chuvas que as dimensionadas para o projeto (Cormier; Pellegrino, 2008; Moura, 2013).

Biovaleta (Figura 3) é similar ao jardim de chuva, a diferença está no tipo de solo, que neste caso não possuindo adequada capacidade de infiltração (como os argilosos) dissipa a água na sua extensão e esta é lançada na rede tradicional de drenagem pluvial. Tanto jardim de chuva como biovaleta promovem o benefício adicional de filtragem das águas, principalmente dos primeiros 10 minutos iniciais de chuva, a qual é a mais rica em contaminação.

Figura 2. Jardim de chuva junto ao meio fio. Fonte: Portland, 2016.
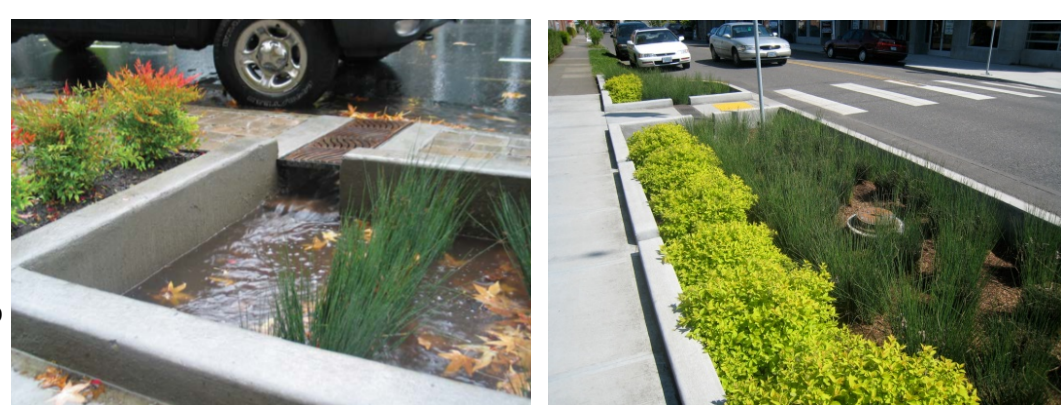

Figura 3. Biovaleta em Portland [EUA]. Fonte: Portland, 2016.

Dentro da visão da infraestrutura verde recomenda-se o pavimento permeável em calçadas e ciclovias, pois é uma tipologia que fornece o benefício da infiltração das águas pluviais e mitigação das ilhas de calor urbanas (Qin \& Hiller, 2016; Maruyama \& Franco, 2016).

A análise do critério de arborização urbana considerou a sensação térmica e percepção do grau de sombreamento observados pelos pesquisadores em visita a campo. Foram estabelecidas as classificações de ruas áridas, semiáridas e arborizadas, conforme a constatação dos pesquisadores enquanto usuários dos espaços. 
A verificação das ilhas de calor urbanas adotou as seguintes etapas. Primeiro o mapa de temperatura da Prefeitura de São Paulo (1999) foi georeferenciado e aplicado no programa QGIS, a seguir sobre este mapa foi adicionada a buffer zone de estudo. A seguir foram feitas análises das ilhas de calor urbanas presentes na área de estudo e a partir disto foram elaboradas proposições para mitigação destes efeitos, fatos relatados nos resultados e discussão.

\section{Resultados e discussão}

\subsection{Análise por ponto de coleta de dados}

A visita de campo teve início no ponto 01, o qual se localiza na entrada do Parque da Água Branca na Avenida Francisco Matarazzo e possui densa arborização (Figura 4). A visita de campo se deu durante dias úteis de semana em horário comercial. A avenida principal, Francisco Matarazzo, é arterial e possui canteiro central utilizado na travessia de pedestres. Além disso, apresenta alguns abrigos de ônibus no canteiro os quais tornam o local inadequado para caminhada (Figura 5). $\mathrm{Na}$ Figura 6 temos uma ilustração da área de estudo geral, com indicação das ampliações e transeptos executados.

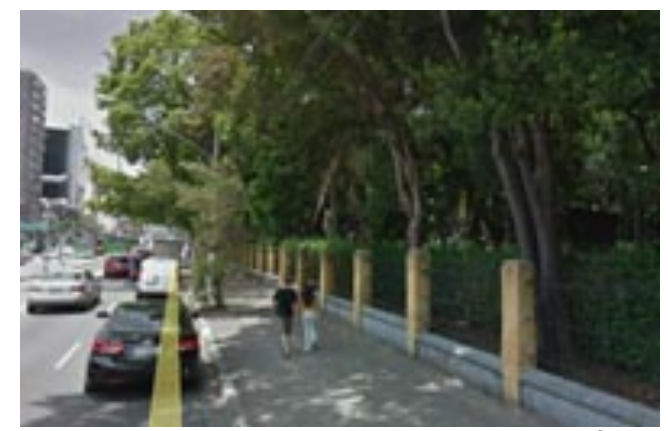

Figura 4. Calçadas na região do Parque da Água Branca indentificadas como arborizadas. Fonte: Google Maps (2017).

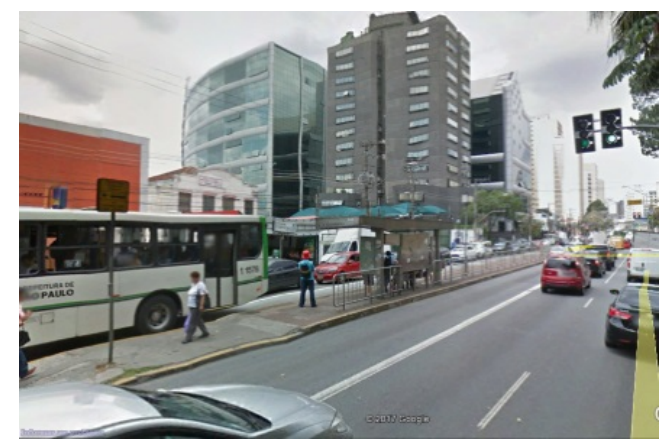

Figura 5. Exemplo de trecho árido. Fonte: Google Maps (2017).

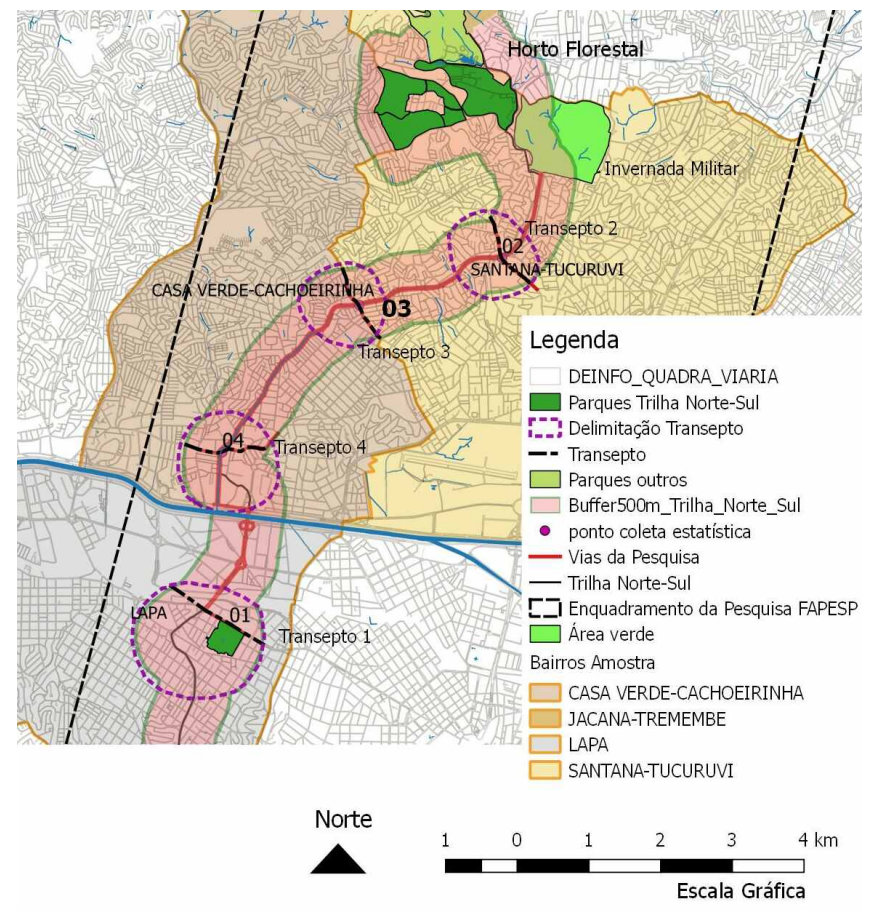

Pontos de coleta das entrevistas: 1- Parque da Água Branca, 2Av. Voluntários da Pátria, 3 - Av. Imirim, 4 - Av. Casa Verde

Na Figura 7 tem-se a ilustração da imagem de satélite da ampliação do ponto 1 e a o transepto ${ }^{2} 1$, o qual foi dramatizado em três vezes na escala vertical para melhor visualização. Nesta figura observa-se a topografia relativamente plana da região, assim como a intensa verticalização da área e a presença de alguns fragmentos de verde representados pelas árvores no transepto.

O próximo local de coleta de dados foi o ponto 02, no cruzamento entre a R. Voluntários da Pátria e Avenida Caetano Álvares. As entrevistas ocorreram numa área próxima a um supermercado e a uma praça, devido à maior presença de pessoas. A região é caracterizada por ser arborizada nos logradouros, além da presença de praças e lotes com ilhas de verde. Conta com arborização significativa no canteiro central da Av. Engenheiro Caetano Álvares (Figura 8). Já a Rua Voluntários da Pátria é marcada por topografia inclinada e diversas "rampas" nas calçadas, fato que causa desconforto à caminhada (Figura 9).

2 Transepto é a seção transversal da via, transecto é a seção longitudinal (nota dos autores). 

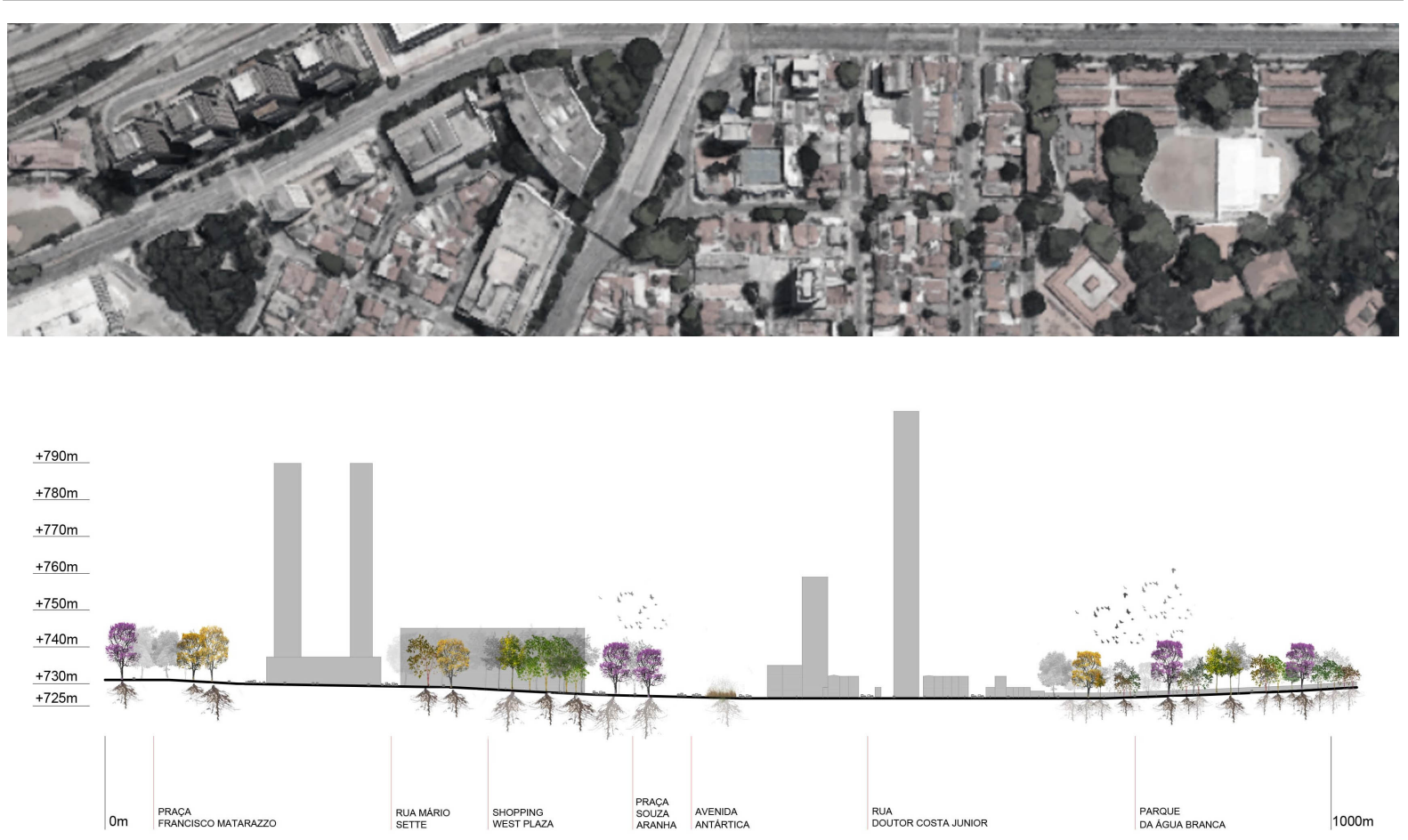

Figura 7. Transepto do ponto 1 - Parque da Água Branca. Fonte: Google Earth (2017) editado por Laís Padilha Leite; Lívia Duailibe; Natalie Barusso (2017).

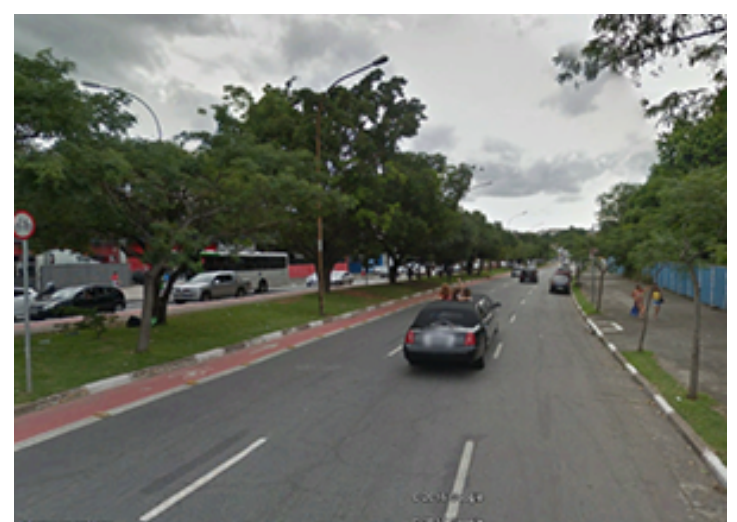

Figura 8. Avenida Engenheiro Caetano Álvares, identificado como canteiro arborizado.

Fonte: Google Maps (2017).

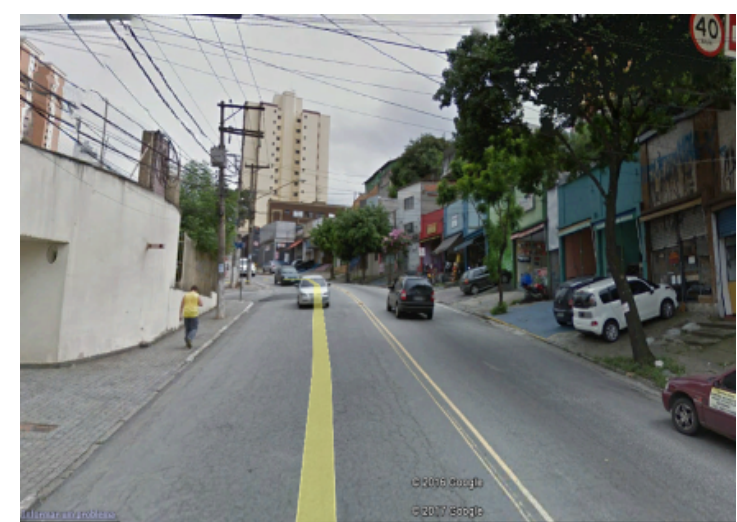

Figura 9. Calçada da Avenida Voluntários da Pátria, sentido Norte com rampas.

Fonte: Google Maps (2017).

Na Figura 10 temos o transepto do ponto 2, onde podemos observar a topografia mais acidentada da Rua Voluntários da Pátria e a Av. Eng. Caetano Álvares como ponto baixo da área, o qual recebe as águas da chuva dos pontos mais altos. Nota-se também novamente a verticalização da área assim como a presença de alguns fragmentos significativos de verde.

O próximo ponto de visitação foi o 03 , o qual se localiza no encontro da Avenida Imirim com Avenida Caetano Álvares. Os espaços dotados de verde nesta área são pontuais, concentram-se no canteiro central da avenida, em alguns lotes privados e nas praças. Percebe-se ampla presença de estabelecimentos de serviços de oficinas e de lojas de veículos, os quais conflitam com o trânsito intenso de pedestres (Figura 11). A Avenida Imirim não possui delimitação na calçada entre faixa de serviço e de passeio, o que acaba prejudicando a circulação dos pedestres devido aos inúmeros obstáculos existentes ao longo do percurso (Figura 12).

Na Figura 13 o transepto do ponto 3 ilustra a topografia mais acidentada do lado direito da Avenida Imirim e novamente a Av. Eng. Caetano Álvares como ponto baixo receptor das águas dos pontos mais altos da região. Também nota-se neste trecho as edificações menos verticalizadas e a presença menos significativa de verde em comparação aos pontos 1 e 2 de coleta. Pela imagem aérea percebe-se a 
intensa ocupação do solo, com pouca presença de espaços permeáveis para a infiltração da água e com pouco solo exposto vivo 3 passível de promover trocas de calor com o ambiente.
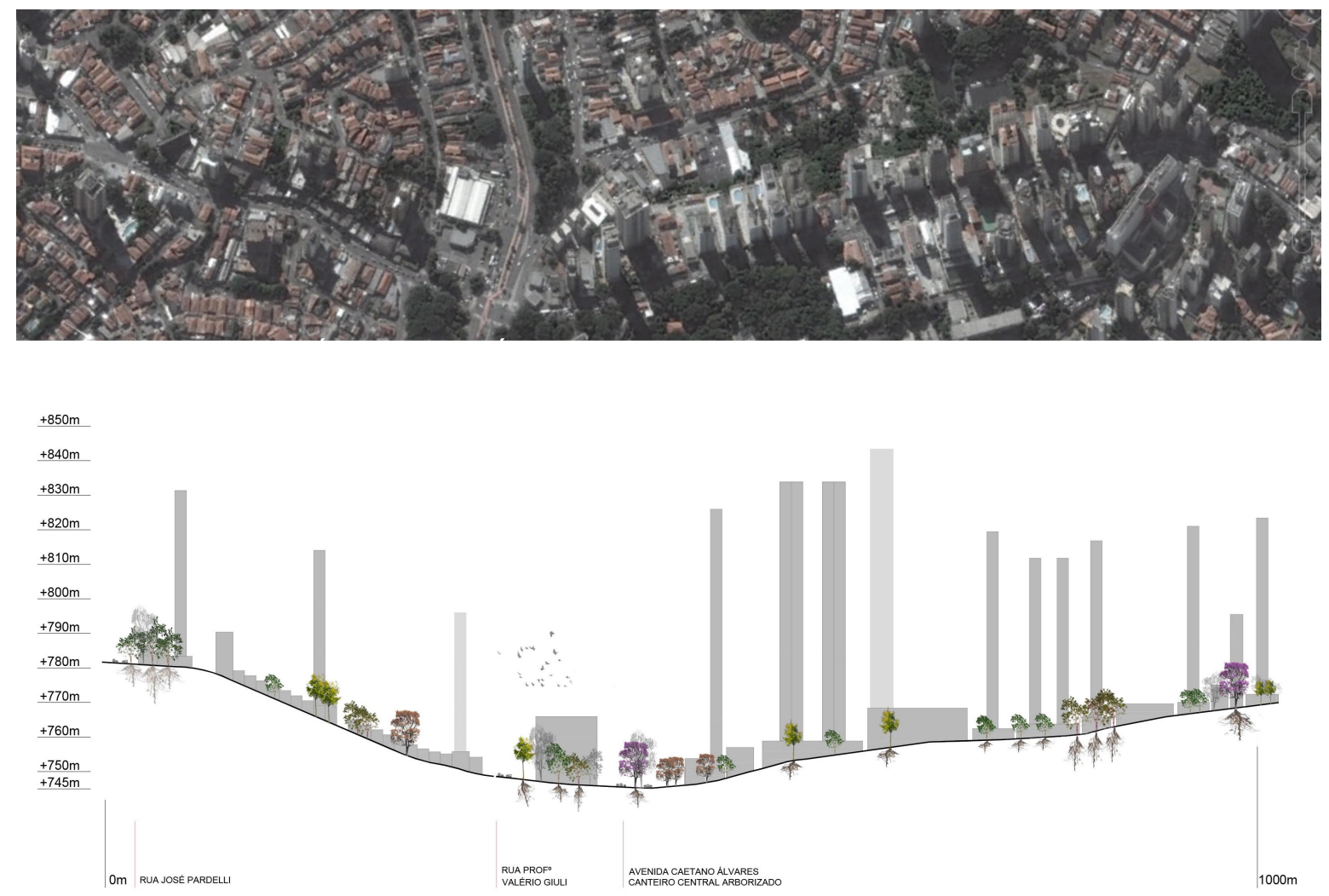

Figura 10. Transepto do ponto 2 - Rua Voluntários da Pátria. Fonte: Google Earth (2017) editado por Laís Padilha Leite; Lívia Duailibe; Natalie Barusso (2017).

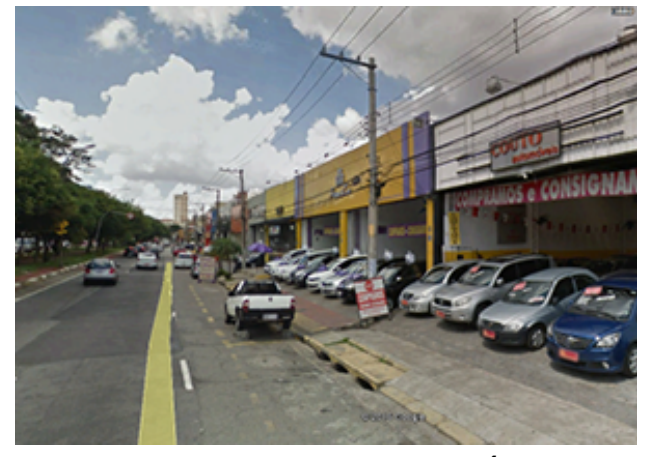

Figura 11. Calçadas da Av. Caetano Álvares com interferências de saída e entrada de veículos. Fonte: Google Maps (2017).

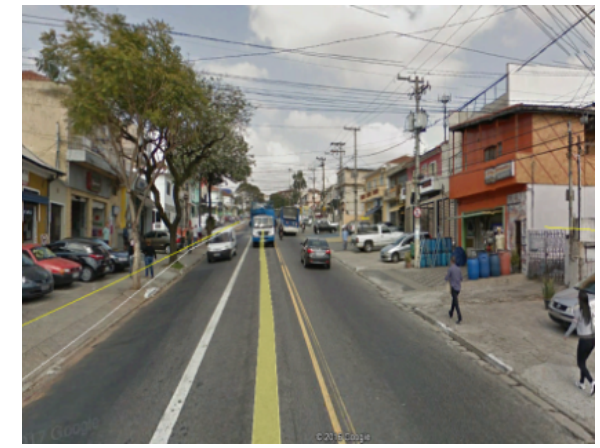

Figura 12. Calçadas na Av. Imirim com a presença de veículos.

Fonte: Google Maps (2017).

Na Figura 14 apresenta-se a seção viária da Av. Imirim existente do lado esquerdo em relação à Av. Eng. Caetano Álvares e na Figura 15 uma proposição de infraestrutura verde. A localização desta seção está indicada na Figura 13. A proposta foi elaborada do lado esquerdo da via onde há topografia mais suave para implantação de infraestrutura cicloviária (Figura 13). Tal proposição considera retirar 1 faixa de rolamento para poder implantar ciclovia bidirecional segregada da calçada com obstáculos de concreto, com afastamento lateral da via de $50 \mathrm{~cm}$ de faixa vegetada com biovaleta ou jardim de chuva, para benefícios nos processos de infiltração da água e segurança viária para o ciclista. Outras melhorias seriam o alargamento da calçada no lado oposto à ciclovia, além do plantio de árvores em ambos os lados da via. Os canteiros das árvores também incluirão biovaletas vegetadas. Na Figura 12 observa-se a presença de rede aérea de fiação do lado direito da via, sugere-se enterrar tal rede para possibilitar plantio de árvore de médio porte.

${ }^{3}$ Solo vivo, é aquele fértil, dotado de microorganismos, que ajudam nos processos de captura de gases de efeito estufa. 

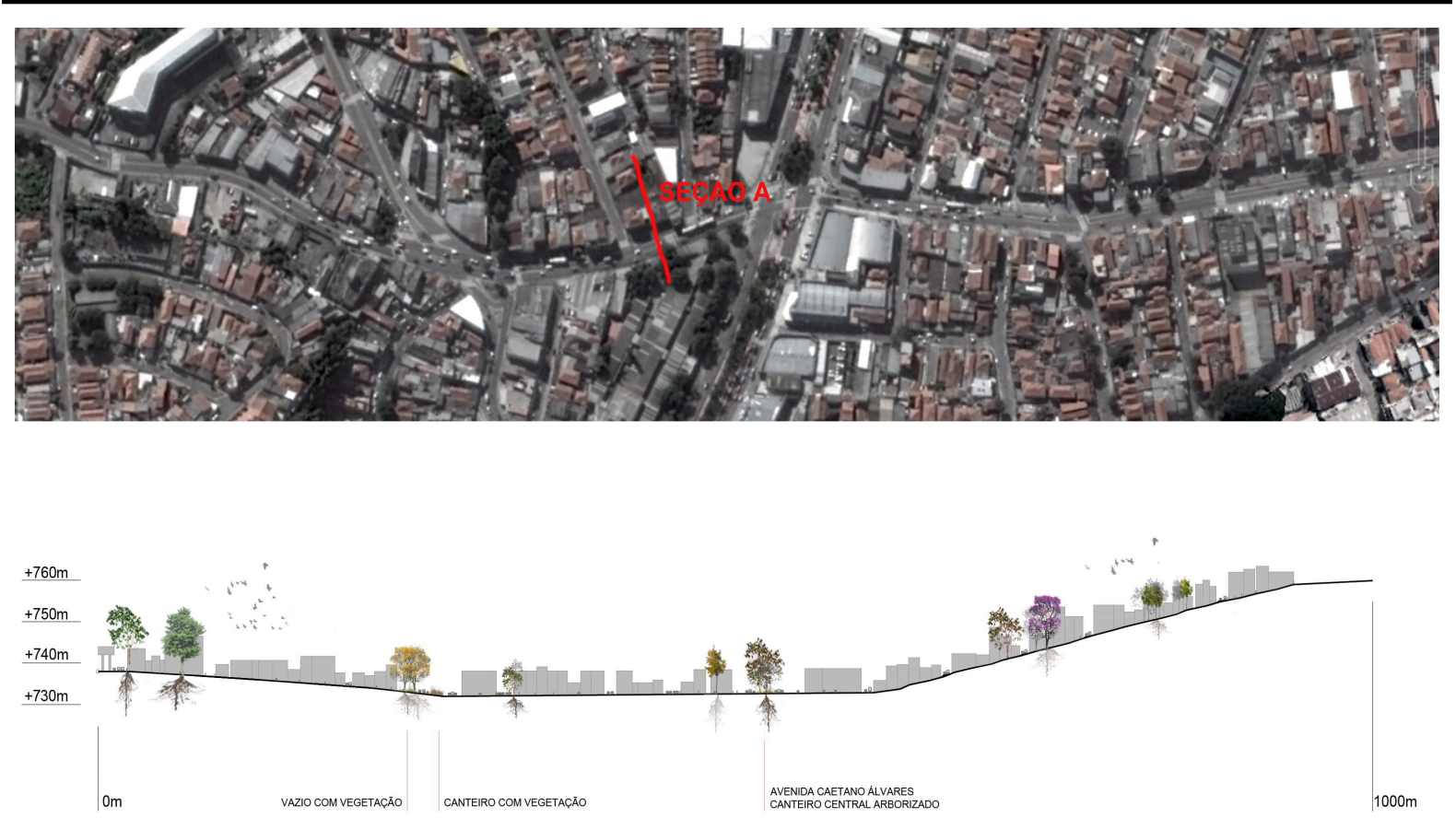

Figura 13. Transepto do ponto 3 - Av. Imirim. Fonte: Google Earth (2017) editado por Laís Padilha Leite; Lívia Duailibe; Natalie Barusso (2017).

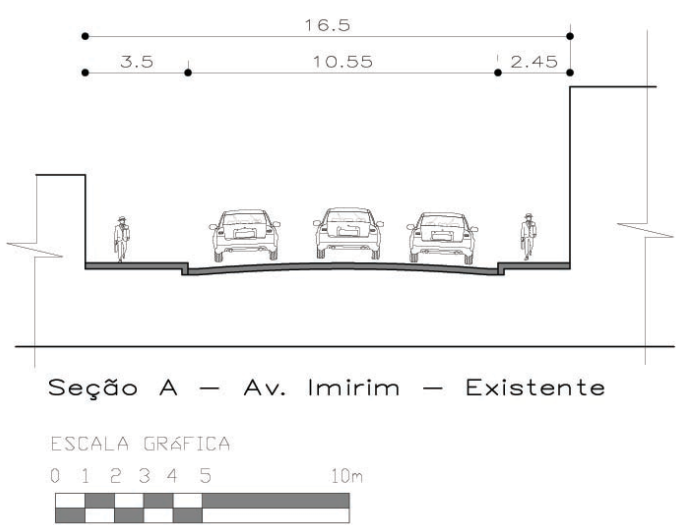

Figura 14. Av. Imirim - existente. Fonte: Google Maps; Cíntia M. Maruyama (2017).

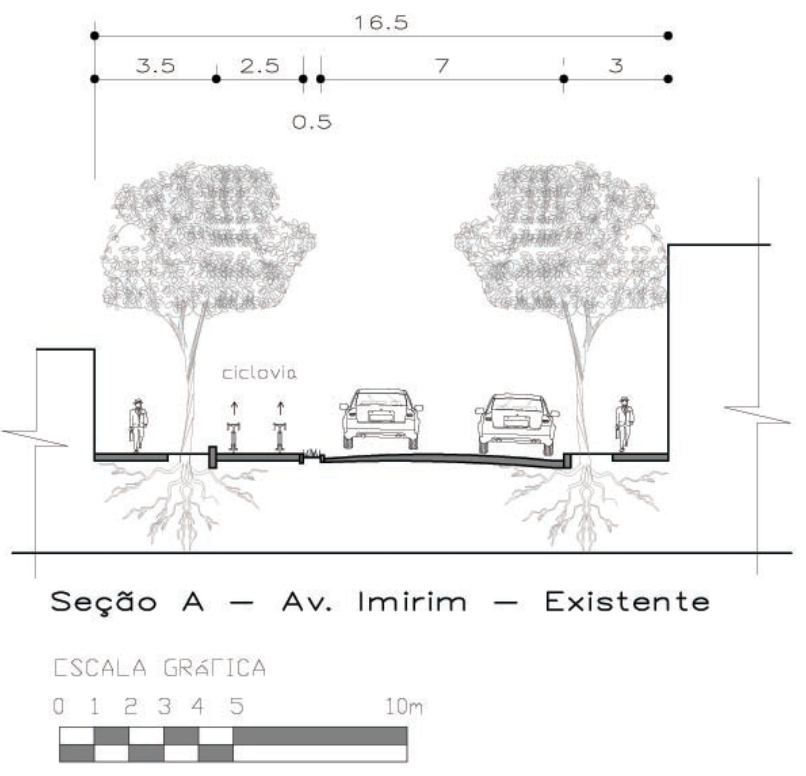

Figura 15. Av. Imirim proposta de infraestrutura verde. Fonte: Google Maps; Autoras (2017).

São propostos pavimentos permeáveis para ciclovias e calçadas (para melhoria dos processos de infiltração das águas da chuva), pavimentos brandos com camada refletiva nas faixas de rolamento ambos para a atenuação das IC.

Ressalta-se que para a retirada da faixa de rolamento outras ações em termos de mobilidade urbana devem ser previstos, como a melhoria do transporte público com, por exemplo, a implantação de modal com maior capacidade que o ônibus, tal como o Veículo Leve sobre Trilhos - VLT nas vias ou outro similar. Tal modal poderia ser alocado no nível da via e para isto outros estudos e projetos devem ser executados. No planejamento viário estes sistemas de transporte podem ser redirecionados para vias paralelas a esta onde está sendo proposta a implantação da infraestrutura verde.

0 ponto 04 está localizado no encontro da Avenida Casa Verde com a Caetano Álvares. Neste trecho não há mais o canteiro central, pois a área abriga o Córrego Mandaqui, o qual sofreu processo de canalização e tamponamento em vários trechos (Figura 16). 
Na Figura 17 o cenário é semelhante ao transepto do ponto 3, mas com a diferença de maior verticalização do lado esquerdo da Av. Casa Verde. Neste trecho notase ainda mais carência de verde do que no ponto 3 de coleta. Na Figura 18 temos um croqui esquemático para uma seção típica existente no ponto 4, cuja posição está demarcada na Figura 17. Na Figura 19 apresenta-se uma proposição para a área dentro da visão da infraestrutura verde. A proposta prevê a retirada de uma faixa de rolamento de cada pista da avenida, para alargamento da seção hidráulica da calha do córrego o qual está canalizado, inclusão de ciclovia, arborização, alargamento de calçadas. Com tal aumento de seção do rio pretende-se diminuir a ocorrência de en- pou chentes e alagamentos, visto que o entorno deste cor-

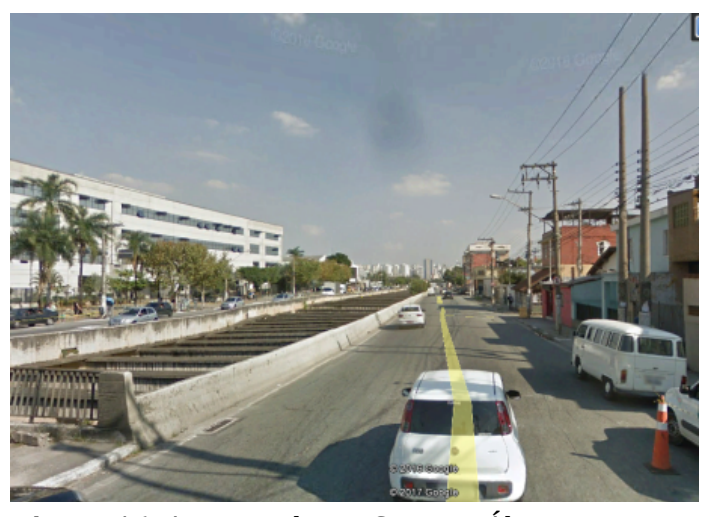

Figura 16. Av. Engenheiro Caetano Álvares com po d'água está densamente ocupado, além do que, co.

mo se observa na foto da Figura 16, o solo está impermeabilizado em grande parte. Tais fatos tornam esta área sensível, pois a ocupação e impermeabilização do solo levam a maior volume e velocidade da água que se direciona ao canal de drenagem. Outro benefício do alargamento deste canal é o ganho de visual do córrego perante o público, fato difícil de ocorrer com a configuração atual. $\mathrm{Na}$ Figura 19 há a previsão de "caminhos" de pedestres sobre algumas áreas pontuais do canal. Sugere-se enterrar a rede aérea de fiação para possibilidade de plantio de árvores de médio porte.
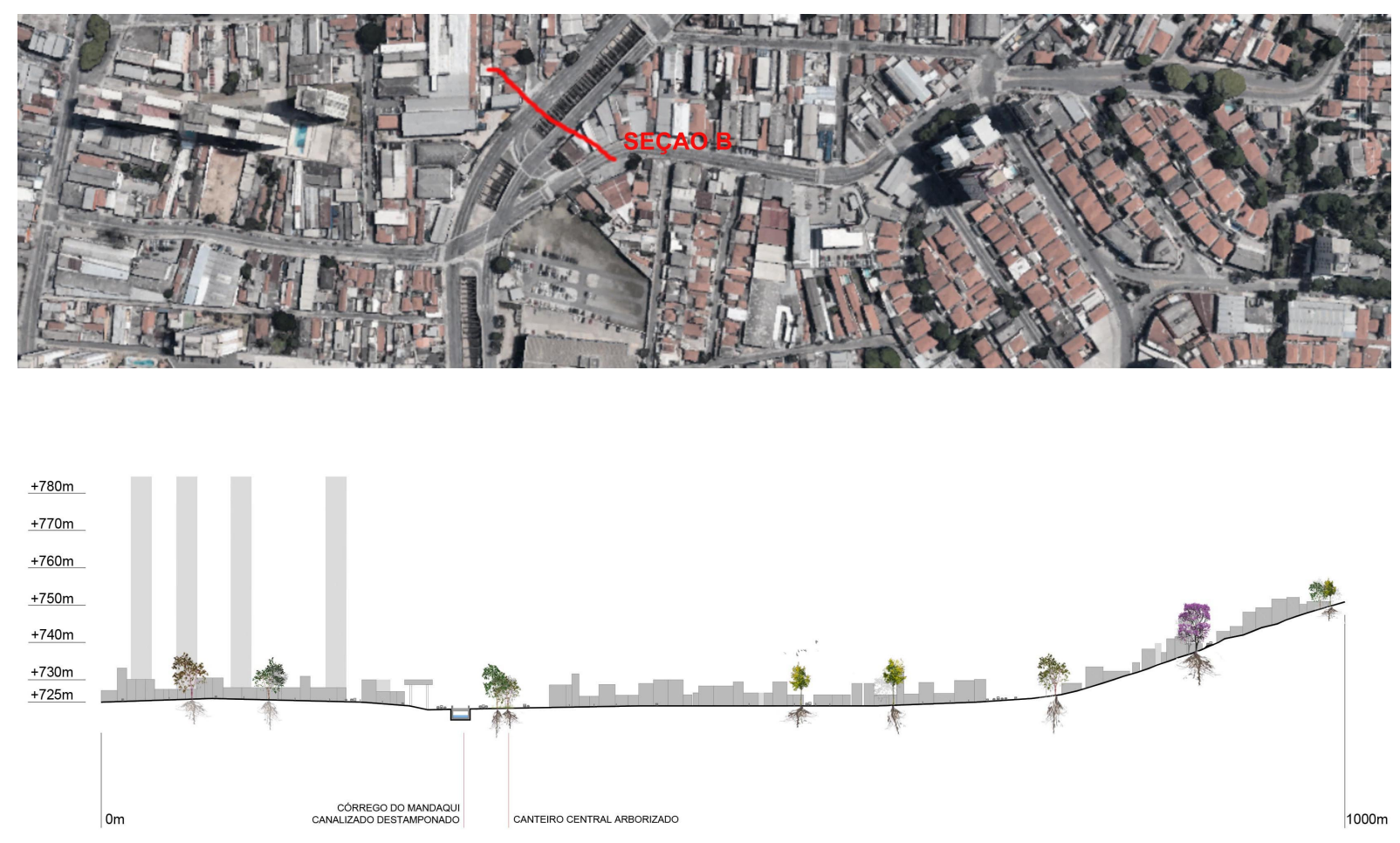

Figura 17. Transepto do ponto 4 - Av. Casa Verde. Fonte: Google Earth (2017) editado por Laís Padilha Leite; Lívia Duailibe; Natalie Barusso (2017).

Na Tabela 1 são apresentados os principais resultados referentes à analise das calçadas e arborização. 0 levantamento junto aos usuários ocorreu entre os dias 7 a 18 de novembro de 2016 e analisou a opinião de 210 pessoas. De modo geral, os resultados da qualificação do público foram os seguintes: a maioria de respostas obtidas foi do público masculino, com $68,09 \%$; a idade média dos entrevistados foi de 20 a 40 anos $(44,68 \%)$ e na faixa de 41 a 60 anos (42,55\%). Foi levantada uma alta taxa de escolaridade, sendo que $40,43 \%$ possuía o ensino superior completo e $3 \%$ concluíram a pós-graduação. Entretanto a renda dos usuários entrevistados foi detectada como baixa, com $61,70 \%$ alegando possuir renda familiar de até 4 salários mínimos. Nas Tabela 2 e 3 são apresentados os principais dados levantados por ponto de coleta. 


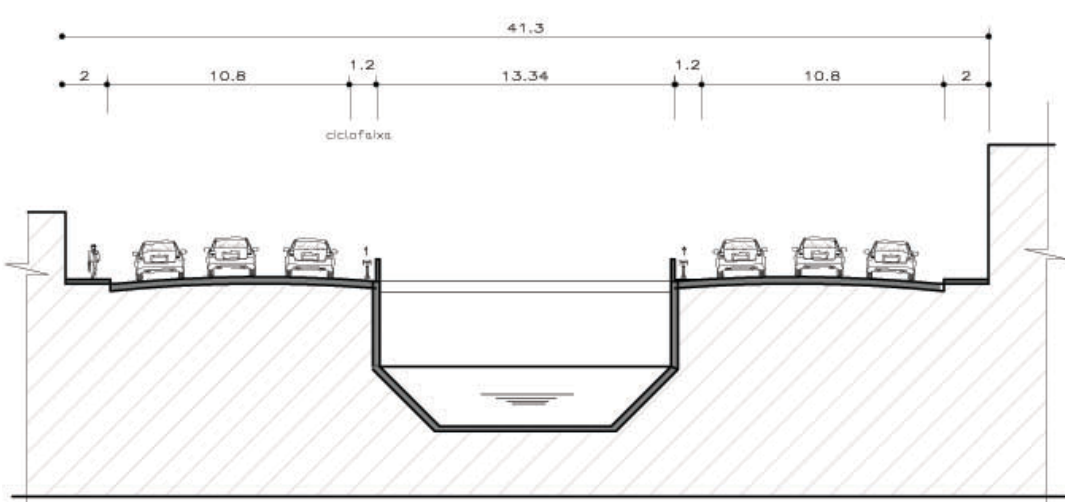

Figura 18. Seção existente B. Fonte: Google Maps; Prefeitura de São Paulo (s/d); Cíntia M. Maruyama (2017).

Seçåo B - Av. Eng. Caetano Alvares - Existente

ISCALA GRATILA

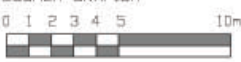

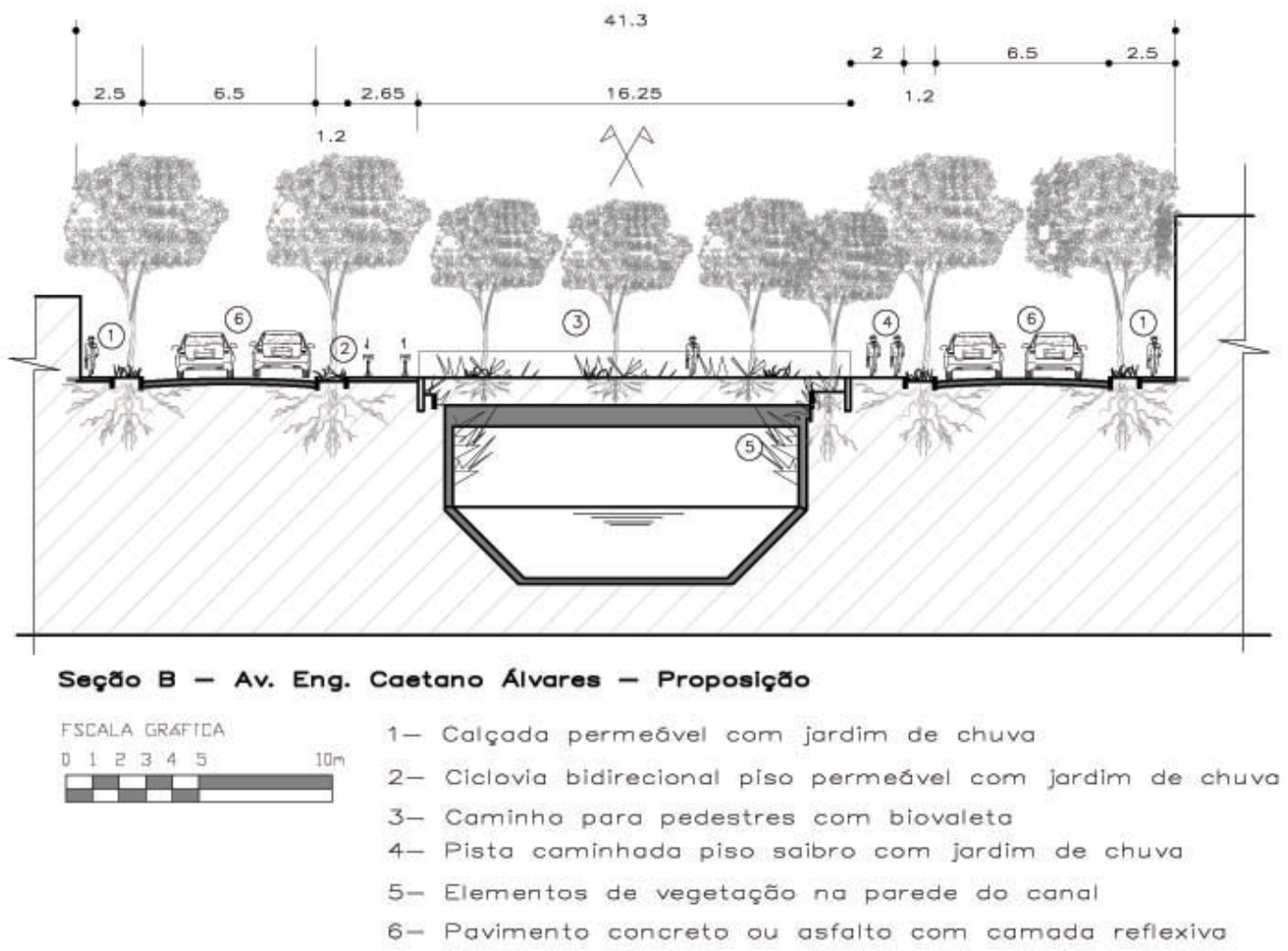

Figura 19. Seção B proposta com infraestrutura verde.

Fonte: Google Maps; Autores (2017).

Tabela 1. Pontos de coleta e os resultados encontrados referentes às caçadas e arborização.

\begin{tabular}{|c|c|c|c|c|}
\hline $\begin{array}{c}\text { Pontos } \\
\text { de }\end{array}$ & Localização & Calçada & Canteiro central & Arborização \\
\hline 1 & $\begin{array}{l}\text { Av. Francisco } \\
\text { Matarazzo x Parque } \\
\text { da Água Branca }\end{array}$ & $\begin{array}{l}\text { Largura regular, entre } 3,5 \mathrm{~m} \text { e } 4,0 \mathrm{~m} \text {, sem } \\
\text { elementos separadores entre veículos e } \\
\text { pedestres }\end{array}$ & $\begin{array}{l}\text { Largura entre } 1,0 \mathrm{~m} \mathrm{e} \\
2,60 \mathrm{~m} \text {. Estreito, } \\
\text { segundo critério de } \\
\text { Prinz (1980) devido ser } \\
\text { avenida arterial e } \\
\text { abrigar pontos de } \\
\text { coletivos }\end{array}$ & $\begin{array}{l}\text { Na calçada e canteiro: } \\
\text { arborizada apenas na } \\
\text { região do parque, } \\
\text { demais trechos áridos } \\
\text { Canteiro: árido }\end{array}$ \\
\hline
\end{tabular}




\begin{tabular}{|c|c|c|c|c|}
\hline & Av. Caetano Álvares & $\begin{array}{l}\text { Piso tipo intertravado em condições } \\
\text { regulares, com largura de } 2,50 \mathrm{~m} \text {, estreita } \\
\text { (via arterial). Falta elemento separador } \\
\text { entre pedestre e veículo }\end{array}$ & $\begin{array}{l}\text { Não possui canteiro } \\
\text { neste trecho pois se } \\
\text { trata de cruzamento } \\
\text { com semáforos }\end{array}$ & $\begin{array}{l}\text { Calçadas e canteiros } \\
\text { arborizados }\end{array}$ \\
\hline 2 & $\begin{array}{l}\text { R. Voluntários da } \\
\text { Pátria } \\
\text { (via coletora) }\end{array}$ & $\begin{array}{l}\text { Sentido Sul: inclui mobiliário urbano e } \\
\text { paradas de ônibus, calçadas com desníveis } \\
\text { devido à topografia, larguras das calçadas } \\
\text { entre } 1 \text { e } 2,0 \mathrm{~m} \text {, estreitas. } \\
\text { Sentido Norte: desníveis nas calçadas } \\
\text { devido à topografia, larguras entre } 2,50 \mathrm{~m} \\
\text { e } 3,0 \mathrm{~m} \text { - estretias }\end{array}$ & Sem canteiro & $\begin{array}{l}\text { Localização das } \\
\text { árvores atrapalha a } \\
\text { circulação de } \\
\text { pedestres }\end{array}$ \\
\hline \multirow[t]{2}{*}{3} & Av. Caetano Álvares & $\begin{array}{l}\text { Largura entre } 4,0 \mathrm{~m} \text { e } 5,0 \mathrm{~m} \text { (adequada), } \\
\text { piso adequado }\end{array}$ & $\begin{array}{l}\text { Canteiro largo, com } \\
\text { média de 5,0m de } \\
\text { largura (adequada). } \\
\text { Ciclofaixas nas laterais } \\
\text { do canteiro }\end{array}$ & $\begin{array}{l}\text { Arborização e } \\
\text { vegetação em áreas } \\
\text { pontuais - } \\
\text { Canteiro central } \\
\text { arborizado } \\
\text { Calçadas áridas }\end{array}$ \\
\hline & Av. Imirim & $\begin{array}{l}\text { Largura entre } 5,0 \text { e } 6,0 \mathrm{~m} \text { (adequado), mas } \\
\text { com desníveis e materiais diversos de } \\
\text { pisos, calçada sem continuidade e } \\
\text { interrompidas por degraus }\end{array}$ & Sem canteiro & Semi áriada \\
\hline \multirow[t]{2}{*}{4} & Av. Caetano Álvares & $\begin{array}{l}\text { Desníveis e obstáculos, largura entre } \\
2,30 \mathrm{~m} \text { e } 1,20 \mathrm{~m} \text { (estreita). Proximidade } \\
\text { entre pedestre e veículos causam sensação } \\
\text { de insegurança }\end{array}$ & $\begin{array}{l}\text { Sem canteiro - pois } \\
\text { abriga o córrego do } \\
\text { Mandaqui - canalizado } \\
\text { ou tamponado em } \\
\text { alguns trechos) }\end{array}$ & árida \\
\hline & Av. Casa Verde & $\begin{array}{l}\text { Via coletora, largura entre } 2,60 \text { e } 3,40 \mathrm{~m} \\
\text { nas calçadas (estreita). Possui paradas de } \\
\text { ônbus, o que torna a calçada ainda mais } \\
\text { estreita }\end{array}$ & Sem canteiro & Semi árida \\
\hline
\end{tabular}

Fonte: Autores (2017).

Tabela 2. Principais resultados das entrevistas sobre hábito de caminhar.

\begin{tabular}{|c|c|c|c|c|}
\hline Ponto & $\begin{array}{l}\text { Hábito de } \\
\text { caminhada }\end{array}$ & $\begin{array}{l}\text { Para quem respondeu que } \\
\text { faz caminhada, } \\
\text { "Por onde você caminha?" }\end{array}$ & $\begin{array}{l}\text { "Você se sente } \\
\text { bem e com } \\
\text { qualidade de } \\
\text { vida ao } \\
\text { caminhar pelo } \\
\text { seu bairro?" }\end{array}$ & $\begin{array}{l}\text { Por que não se sente bem ao } \\
\text { caminhar pelo bairro? }\end{array}$ \\
\hline 1 & $\begin{array}{l}\text { Sim: } 74 \% \\
\text { Não: } 26 \%\end{array}$ & $\begin{array}{l}\text { A maioria respondeu que caminha } \\
\text { no Parque da Água Branca. } \\
\text { Outras respostas apuradas: na } \\
\text { ciclovia da Av. Sumaré, nas } \\
\text { calçadas ao redor do bairro, na Av. } \\
\text { Sumaré e em parques }\end{array}$ & $\begin{array}{l}\text { Sim: } 74 \% \\
\text { Não: } 26 \%\end{array}$ & $\begin{array}{l}38 \% \text { sensação de poluição } \\
11 \% \text { devido à pouca arborização, } \\
\text { sombreamento e muito calor } \\
33 \% \text { acha inseguro } \\
18 \% \text { consideram as calçadas inadequadas }\end{array}$ \\
\hline 2 & $\begin{array}{l}\text { Sim: } 50 \% \\
\text { Não: } 50 \%\end{array}$ & $\begin{array}{l}\text { A maioria respondeu que caminha } \\
\text { na Av. Eng. Caetano Álvares, } \\
\text { outros locais citados: Horto } \\
\text { Florestal, calçadas do bairro, } \\
\text { Praça do Mandaqui, Jardim França }\end{array}$ & $\begin{array}{l}\text { Sim: } 45 \% \\
\text { Não: } 55 \%,\end{array}$ & $\begin{array}{l}44 \% \text { - Inadequação das calçadas } \\
25 \% \text {-Insegurança, } \\
15 \% \text { - Pouca arborização e muito calor } \\
6 \% \text { - Poluição } \\
10 \% \text { - outros motivos }\end{array}$ \\
\hline 3 & $\begin{array}{l}\text { Sim: } 48,28 \% \\
\text { Não: } 51,72 \%\end{array}$ & $\begin{array}{l}51,14 \% \text { dos entrevistados } \\
\text { respondeu caminhar no canteiro } \\
\text { da Av. Eng. Caetano Álvares. } \\
\text { Outras respostas: calçadas do } \\
\text { bairro, Parque da Juventude e } \\
\text { Horto Florestal }\end{array}$ & $\begin{array}{l}\text { Sim: } 56,90 \% \\
\text { Não: } 43,10 \%\end{array}$ & $\begin{array}{l}40 \% \text {-Inadequação das calçadas } \\
28 \% \text { - Insegurança, } \\
5 \% \text { - Pouca arborização e muito calor } \\
25 \% \text { - Poluição } \\
2 \% \text { - outros motivos }\end{array}$ \\
\hline
\end{tabular}




\begin{tabular}{|c|c|c|c|c|}
\hline 4 & $\begin{array}{l}\text { Sim: } 55,32 \% \\
\text { Não: } 44,68 \%\end{array}$ & $\begin{array}{c}\text { 46,15\% respondeu na Av. Casa } \\
\text { Verde, outras respostas: Av. Eng. } \\
\text { Caetano Álvares, Av. Inajah e Av. } \\
\text { Imirim }\end{array}$ & $\begin{array}{l}\text { Sim: } 72 \% \\
\text { Não: } 28 \%\end{array}$ & $\begin{array}{l}\text { 8\% - Inadequação das calçadas } \\
3 \% \text {-Insegurança, } \\
0 \% \text { - Pouca arborização e muito calor } \\
40 \% \text { - Poluição } \\
49 \% \text { - outros motivos }\end{array}$ \\
\hline
\end{tabular}

Fonte: Autores (2017).

Tabela 3. Principais resultados sobre percepção da arborização e caminhada.

\begin{tabular}{|c|c|c|}
\hline \multirow{2}{*}{ Ponto } & \multicolumn{2}{|c|}{$\begin{array}{c}\text { Percepção da arborização do bairro } \\
\text { Entrevistados que alegaram que se o bairro fosse } \\
\text { mas arborizado, caminharia mais a pé }\end{array}$} \\
\cline { 2 - 3 } 1 & $\begin{array}{c}\text { Insuficiente: } 54 \% \\
\text { Suficiente: } 41 \% \\
\text { Não sabe: } 5 \%\end{array}$ & Sim: $65 \%$ \\
& Não: $28 \%$ \\
& Insuficiente: $52 \%$ & Não sabe: $7 \%$ \\
\hline & Suficiente: $45 \%$ & Sim: $77 \%$ \\
& Não sabe: $3 \%$ & Não: $23 \%$ \\
& Insuficiente: $56 \%$ & Sim: $81 \%$ \\
& Suficiente: $44 \%$ & Não: $17 \%$ \\
& Insufificente: $96 \%$ & Não sabe: $2 \%$ \\
& Suficiente: $4 \%$ & Sim: $94 \%$ \\
& & Não: 46 \\
\hline
\end{tabular}

Fonte: Autores (2017).

Analisando os dados verificados pelos pesquisadores em campo e comparando com os resultados das entrevistas obtido por ponto de coleta observamos alguns aspectos. No ponto 1 as calçadas foram identificadas pelos pesquisadores como estreitas e arborizadas, mas ainda assim a maior parte dos entrevistados alegou se sentir bem ao caminhar pelo bairro. Talvez a explicação resida no fato da maior parte das pessoas terem o hábito da caminhada no Parque da Água Branca. Dos 4 pontos de coleta o ponto 1 foi o que apresentou o maior percentual de pessoas $(74 \%$ dos entrevistados) as quais alegaram terem o hábito de se exercitar caminhando, novamente o possível motivo para isto seja a existência do parque da Água Branca nesta região.

No ponto 2 as calçadas foram analisadas como estreitas tanto na Av. Eng. Caetano Álvares como na Rua Voluntários da Pátria, esta última com o agravante de possuir desníveis. Os usuários da área têm a percepção destes problemas e a maioria (55\%) alegou não se sentir bem ao caminhar pela região e o principal motivo alegado foi mesmo a inadequação das calçadas.

No ponto 3 a avaliação das calçadas como inadequada se deu no trecho da Av. Imirim e novamente os usuários têm a percepção deste fato negativo e alegou não se sentir bem ao caminhar pela região. Novamente, a principal alegação para isto, foi a inadequação das calçadas.

No ponto 4 as calçadas foram consideradas estreitas e áridas, mas neste ponto notou-se que os usuários não têm esta percepção, pois apenas a minoria (28\% dos entrevistados) afirmou não se sentir bem ao caminhar pela área. Destes, apenas $8 \%$ dos entrevistados observou como motivo a inadequação das calçadas.

\subsection{Análise global dos pontos de coleta de dados}

A respeito da questão da opinião dos entrevistados sobre a arborização e a qualidade do calçamento e sua repercussão no hábito de caminhada, os resultados obtidos para o total de entrevistas realizadas nos 4 pontos de coleta foram os seguintes. Grande parte dos usuários têm o hábito da caminhada e os locais mais mencionados para tal prática foram o Parque da Água Branca (29\% das 
respostas), seguido da Avenida Eng. Caetano Álvares e as calçadas do bairro. A maior parte do público $(80 \%)$ alegou a intenção de praticar mais caminhadas se a região fosse mais arborizada. As Figuras 20 e 21 ilustram os principais resultados.

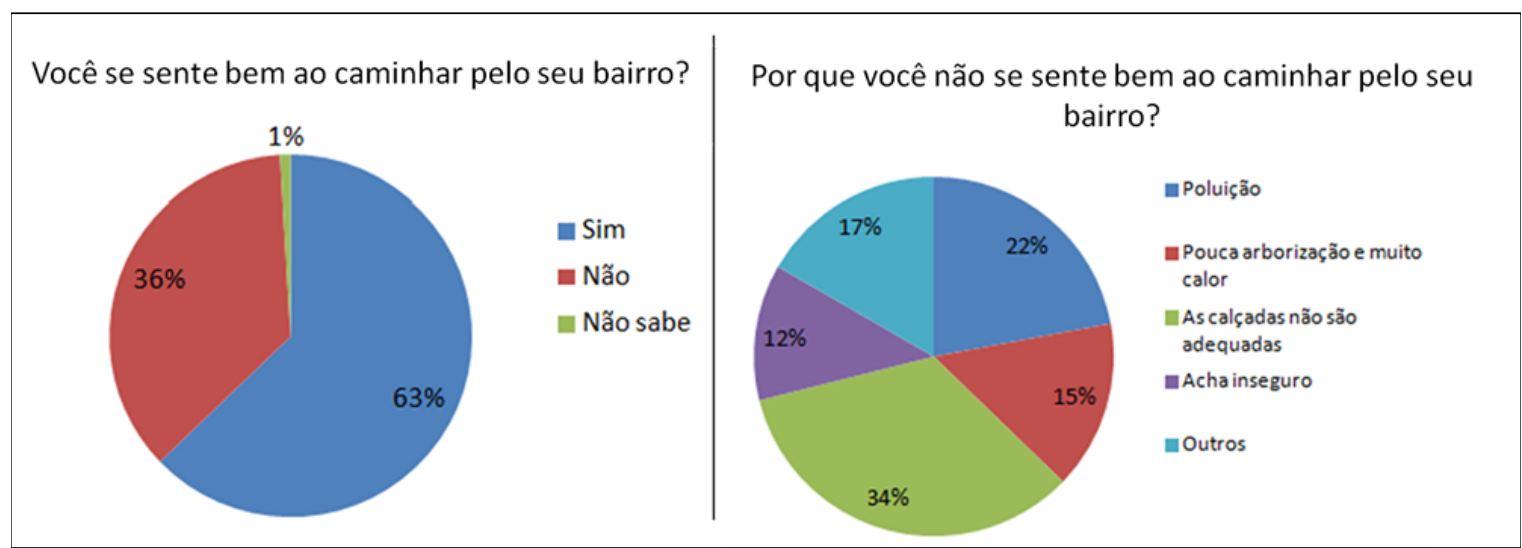

Figura 20. Ilustrações de gráficos com resultados das entrevistas quanto à qualidade da caminhada, como os totais dos 4 pontos de coleta de dados. Fonte: Autores (2017).

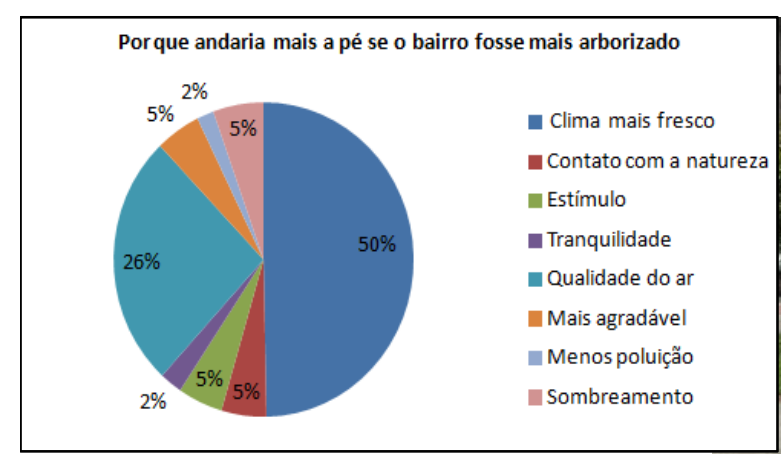

Figura 21. Gráfico com resultados das entrevistas com relação à arborização e prática da caminhada com resultados totais dos 04 pontos. Fonte: Autores (2017).

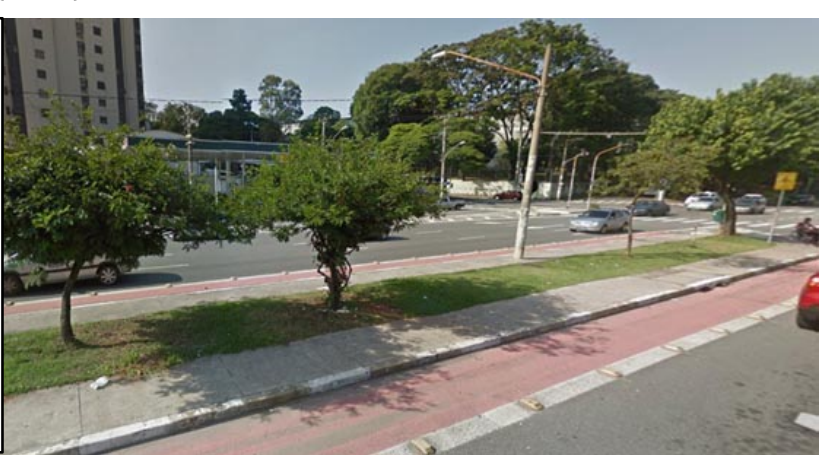

Figura 22. Ciclofaixa da Av. Eng. Caetano Álvares no ponto 2 de coleta (próximo Av. Voluntários da Pátria). Fonte: Google Maps (2016).

Uma parcela dos usuários afirmou caminhar pelas ciclovias e ciclofaixas da Av. Engenheiro Caetano Álvares, tais respostas foram identificadas nos pontos 2 (Figura 22) e 4 de coleta. A ciclovia da Av. Sumaré também foi mencionada como local para a prática de caminhada. A ciclofaixa e a ciclovia são espaços de circulação exclusivo para a bicicleta e tal interação com pedestre pode ser perigosa, especialmente se os ciclistas estiverem em altas velocidades. As possíveis explicações para o uso indevido destes espaços cicloviários são a estreiteza da pista de caminhada nestes pontos, a falta de espaços de lazer e esportes, assim como o fato destas avenidas serem bem arborizada nestes trechos. Outra possível explicação é a falta de conhecimento do público quanto ao fato da ciclovia ser área de circulação exclusiva de bicicleta, campanhas de informação seriam necessárias para conscientização da população.

A caminhada como forma de exercício é muito praticada em locais como parques e praças. Assim, os entrevistados também foram indagados quanto à sua percepção da existência no bairro de praças e parques. Os resultados obtidos indicaram que a maioria (59\% dos entrevistados) percebe haver falta de tais áreas de lazer no seu bairro. As Figuras 23, 24 e 25 ilustram tal situação, a qual foi realmente verificada após análise por fotografia aérea da área de estudo.

Ao analisarmos a Figura 23, observamos que na área de estudo estão presentes dois parques, no ponto 1 o Parque da Água Branca e na região do ponto 2 de coleta o Parque Horto Florestal. Na região do ponto 2 existe também uma grande área verde, mas que se encontra fechada ao público, denominada Invernada da Polícia Militar. Quanto às praças, pela visita a campo e observação em imagens aéreas é fato haver poucas praças no trecho em estudo.

0 ponto 1 (Figura 24) é a que possui algumas praças, além da região do ponto 2 (Figura 25), próximo à Rua Voluntários da Pátria a qual se mostrou mais bem servida neste sentido, tanto que $32,12 \%$ 
do total de entrevistados dos 4 pontos de coleta afirmou frequentar a Praça Mandaqui, localizada no referido ponto de coleta. Nesta mesma área existem outras praças, próximas aos fundos da Invernada da Polícia Militar. Mas a visita em campo e relatos de moradores do bairro revelaram que estes últimos são locais inseguros, dominados por usuários de drogas e muitas vezes esconderijos de delinquentes. Por tais motivos não são frequentados pelos entrevistados.

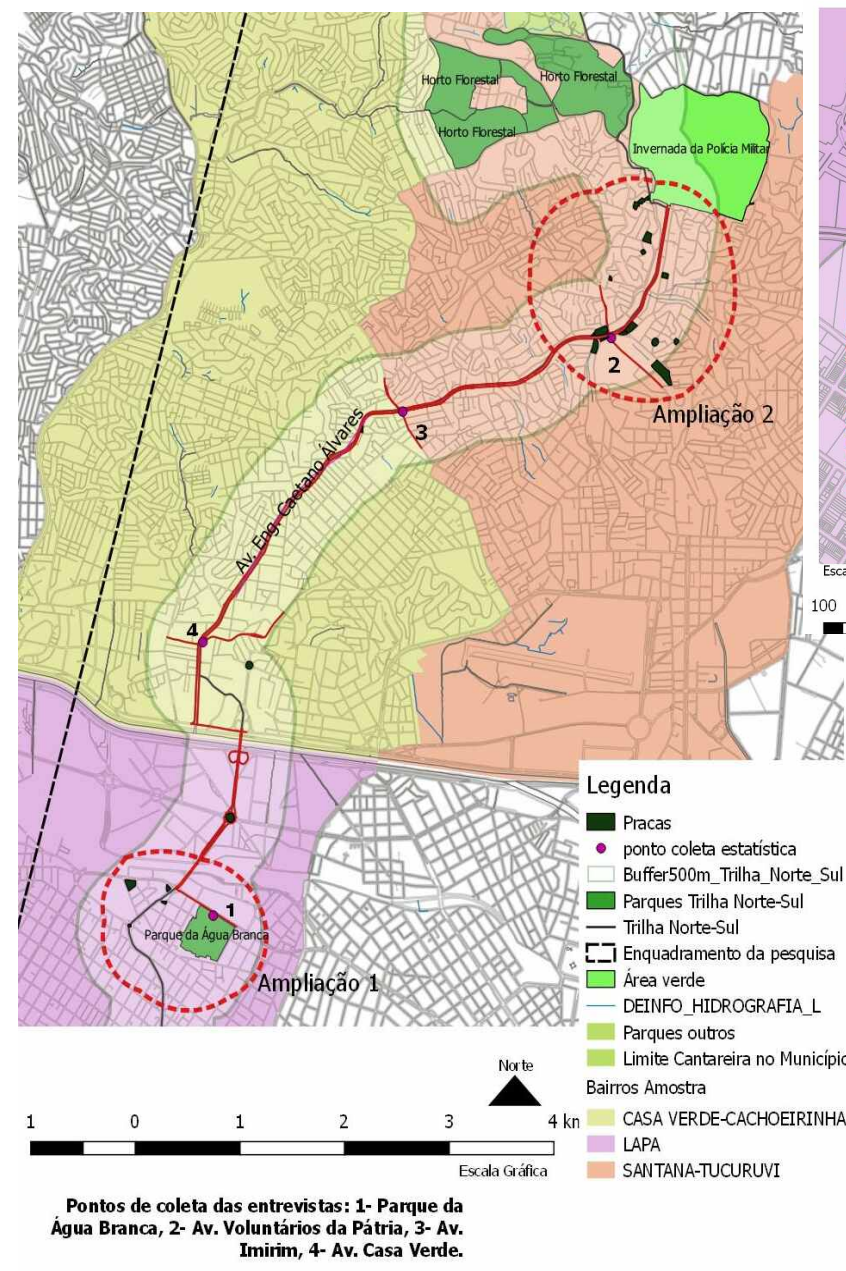

Figura 23. Mapa com ilustração das praças existentes na área de estudo. Fonte: Prefeitura de São Paulo (s/d) e editado pelas autoras (2017).

Na Figura 24 observam-se algumas praças do ponto 1 , mas nota-se que destes 5 equipamentos verificados, 2 são rotatórias denominadas "praças", mas que não cumprem tal função pelo espaço exíguo disponível e pela dificuldade de acesso devido ao movimento dos carros. Então, pode-se afirmar ser esta área carente de praças.

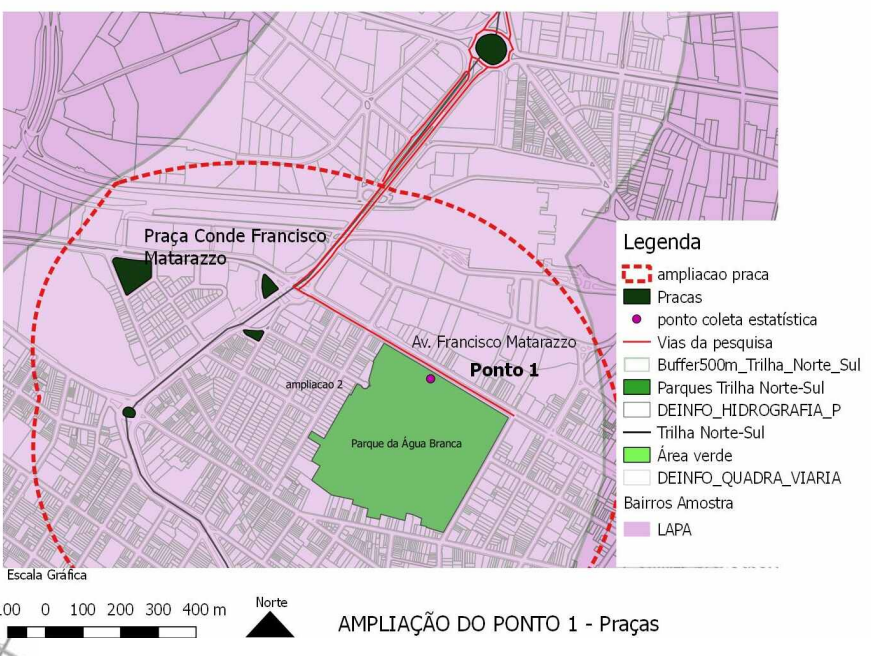

Figura 24. Ampliação das praças do Ponto 1. Fonte: Prefeitura de São Paulo (s/d) e editado pelos autores (2017).

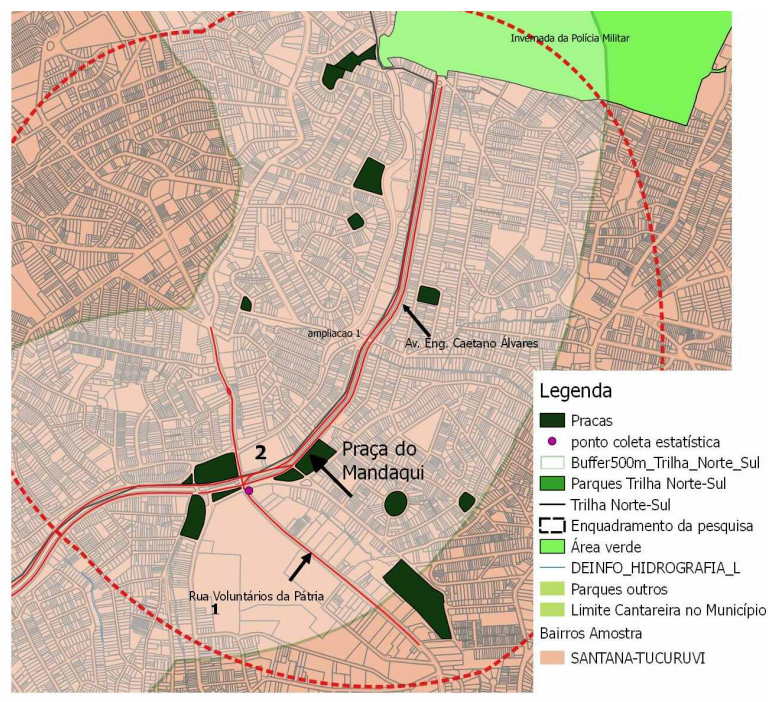

Escala Gráfica

$100 \quad 0 \quad 100200300400 \mathrm{~m}$ Norte AMPLIAÇÃO 1 - Praças do ponto 2

Figura 25. Ampliação das praças do ponto 2. Fonte:

Prefeitura de São Paulo (s/d) e editado pelos autores (2017).

Sobre outra questão referente aos hábitos de frequentar praças e parques, os resultados obtidos indicaram que metade dos entrevistados têm este costume. A principal razão apresentada para quem alegou não ser frequentador foi a falta de segurança, indicativo da necessidade de mais investimentos nesta área em termos de segurança pública. Além de mais efetivo policial outras ações podem ser aplicadas, como a melhoria da iluminação principalmente nas praças públicas.

Outra questão abordada nas entrevistas foi a relacionada a qual parque ou praça as pessoas costumam frequentar. Os locais mais citados foram: Praça do Mandaqui $(32,12 \%)$, Parque da Água Branca $(28,48 \%)$ e Horto Florestal $(13,94 \%)$. 0 possível motivo é a proximidade de tais áreas de lazer à moradia dos entrevistados. Foi interessante observar o fato de outros locais fora da área de 
estudo serem mencionados, como o Parque da Juventude (5,45\%) e o Parque Villa Lobos $(3,64 \%)$. A maioria dos entrevistados que respondeu frequentar o Parque Villa Lobos pertenciam ao ponto 1 de coleta, novamente a proximidade pode ser o motivo por tal opção, pois este parque está a aproximadamente $8 \mathrm{~km}$ do ponto 1 de coleta. Da mesma forma as respostas positivas quanto ao hábito de frequentar o Parque da Juventude foram obtidas no ponto 3 de coleta, o qual está a cerca de $6 \mathrm{~km}$ de distância desta área de lazer.

\subsection{Ilhas de Calor}

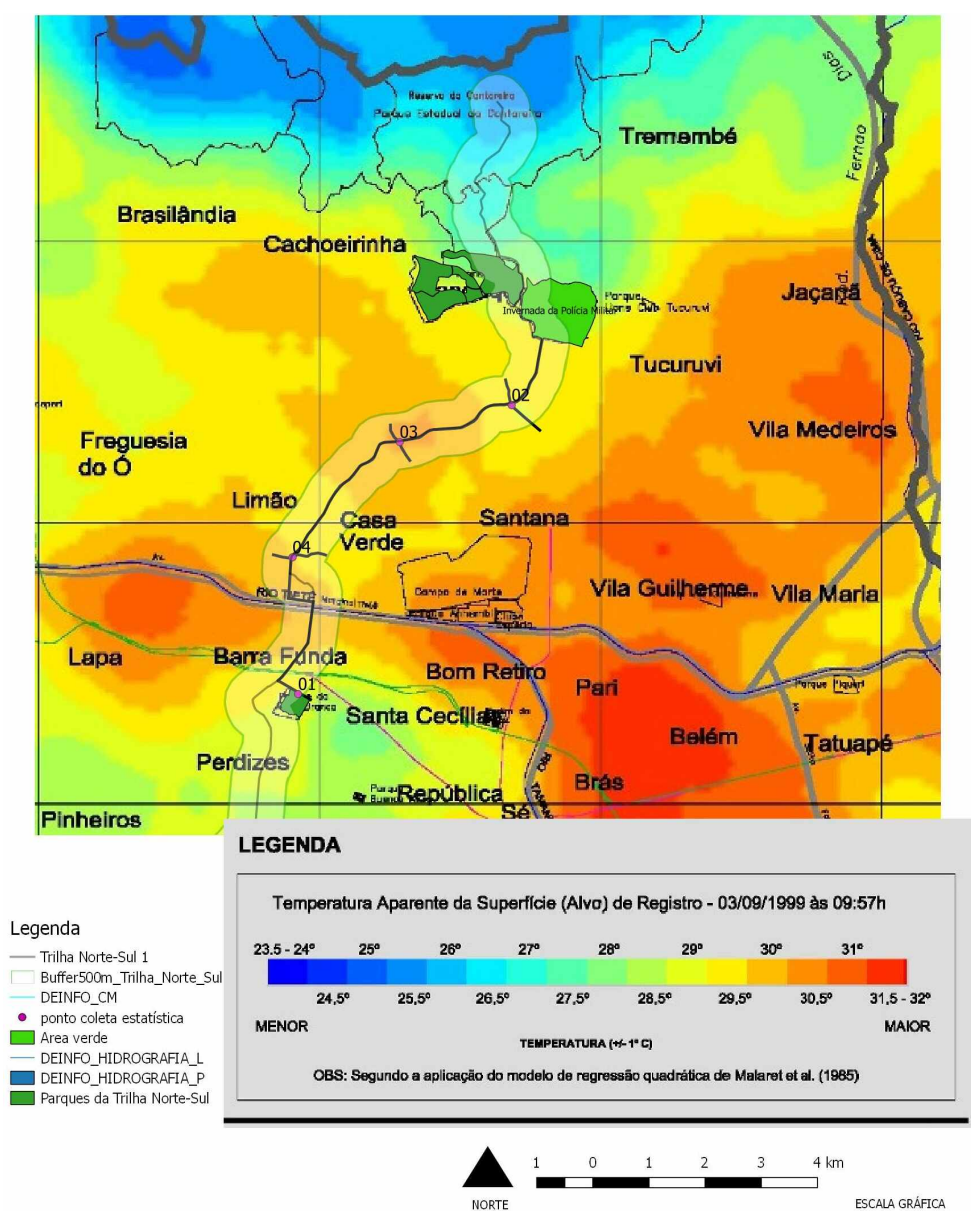

A análise do mapa da Prefeitura Municipal de São Paulo (1999) feita na área da buffer zone de estudo indicou a presença de Ilhas de Calor - IC (Figura 26). As temperaturas mais altas foram observadas nas regiões classificadas como áridas e semiáridas, respectivamente na região do ponto 3 , com $30,5^{\circ} \mathrm{C}$ e no ponto 4 de coleta, com $30^{\circ} \mathrm{C}$. Por outro lado, as áreas mais frias com $29,5^{\circ} \mathrm{C}$ foram verificadas nos pontos 1 e 2 , as quais foram identificadas como arborizadas e dotadas de presença significativa de verde. Estes resultados sugerem a possibilidade de haver uma conexão entre existência de verde e temperatura mais baixa do ar, sendo que a presença da arborização pode ter importante significado neste sentido. Sendo assim é recomendável o plantio de árvores em grande escala para mitigar os efeitos das IC. O ideal para a atenuação deste problema é a adoção conjunta do tripé: da vegetação (principalmente das árvores), pavimentos brandos e tetos verdes. Deste modo há a possibilidade de diminuir em cerca de $3^{\circ} \mathrm{C}$ a temperatura das IC Figura 26. Mapa de Temperaturas com indicação da presença de ilhas de (Rosenfeld et al., 1998), além de recalor na buffer zone. Fonte: Secretaria do Verde e do Meio Ambiente (1999); Prefeitura de São Paulo (s.d) e editado pelos autores (2017). duzir poluentes como ozônio e melhorar a dinâmica das águas da região, diminuindo o escoamento superficial e evitando assim a sobrecarga dos canais de drenagem e os problemas inúmeros que isto acarreta (alagamentos, enchentes, prejuízos diversos). Se for efetivada tal redução de $3^{\circ} \mathrm{C}$, numa área onde a temperatura constatada na Figura 26 constava $30,5^{\circ} \mathrm{C}$ reduziria a $27,5^{\circ} \mathrm{C}$, o que em termos práticos significa estar numa zona de conforto térmico. Isto traria inúmeros benefícios, como a sensível redução da necessidade de uso de aparelhos de resfriamento do ar de ambientes internos, economizando energia e trazendo considerável melhoria de qualidade de vida para as pessoas que habitam e utilizam a região. Nota-se também na Figura 26 a influência positiva da grande mancha verde formada pela Serra da Cantareira, onde verificam-se faixas com as mais baixas temperaturas, indicadas nos tons de azul claro escuro. Contribui para tal efeito resfriativo a presença maciça nesta região de vegetação e de inúmeros corpos d'água.

\section{Conclusões}

A partir dos dados analisados obtivemos as seguintes conclusões: podem ser consideradas como adequadas calçadas de trechos da Avenida Francisco Matarazzo e da Avenida Eng. Caetano Álvares. Observa-se de modo geral a necessidade de aumento de largura das calçadas, principalmente nas 
vias mais movimentadas por veículos. Outro fato identificado é a necessidade de incluir faixa verde com biovaletas ou jardins de chuva para dotar de separação entre o tráfego e os pedestres. Foram observadas inadequações nas calçadas da maior parte das vias analisadas, como a Avenida Imirim e Avenida Voluntários da Pátria, pois existem problemas como revestimentos inapropriados, degraus e falta de largura.

Com relação à arborização, os trechos mais problemáticos observados foram o 3, na Avenida Imirim (semiárida) e o ponto 4 (árida) na Avenida Eng. Caetano Álvares e Avenida Casa Verde. No ponto 4 foi identificado outro trecho árido, localizado na Avenida Marginal Tietê até a altura da Avenida Valdemar Martins, onde existe o Ribeirão Mandaqui. Nestas regiões há necessidade de melhoria da arborização, o que também incentivaria a caminhada, já que os entrevistados fizeram tal alegação na pesquisa aplicada. A Avenida Eng. Caetano Álvares foi um dos locais mais mencionados para a prática da caminhada, as explicações possíveis para isto são a significante presença de arborização e a pista com topografia plana, fatos que propiciam conforto na experiência do andar a pé.

Foram observadas ICs na área de estudo, sugestões dentro da visão da infraestrutura verde de possibilidades de amenização deste problema incluem a adoção conjunta de três ações: o plantio em grande escala de dossel arbóreo (aliado a outros estratos vegetais como arbustos e forração), uso de pavimentos brandos (pavimentos com camada reflexiva nas vias e permeáveis nas ciclovias e calçadas) e tetos e telhados verdes. Com a aplicação de tais soluções há expectativa de redução em cerca de $3^{\circ} \mathrm{C}$ da temperatura do ar na região (Rosenfeld et al., 1998), além de promover benefícios de dimimuição de alagamentos e enchentes, melhoria da qualidade visual do ambiente urbano e da qualidade de vida da população.

Outros aspectos observados são os referentes aos parques e praças, destes destacam-se dois pontos. 0 primeiro é relativo à necessidade de melhorar a segurança das praças, o que pode ser feito com ações da segurança pública e também com outras, como por exemplo com a instalação de mais iluminação nestas áreas. 0 segundo se relaciona à necessidade de criação de mais opções de lazer e esporte para os moradores e frequentadores da área em estudo, principalmente parques e outras áreas verdes.

\subsection{Agradecimentos}

Agradecimentos pela colaboração no trabalho a Talal Suleiman Mahmoud pelo auxilio nos cálculos estatísticos; Laís Padilha Leite, Lívia Borges Duailibe de Deus e Natalie Barusso pela colaboração nos levantamentos, análises de dados e elaboração das seções viárias; Roberta Brondani Minussi pela colaboração na revisão do Abstract.

\section{Referências}

Associação Brasileira de Normas Técnicas - ABNT (2004). NBR 9050. Acessibilidade a edificações, mobiliário, espaços e equipamentos urbanos.

Ahern, J., Pellegrino, P., \& Becker, N. (2012). Infraestrutura verde desempenho, estética, custos e método. In: L. M. S. A. Costa \& D. B. P. Machado (orgs.). Conectividade e resiliência: estratégias de projeto para a metrópole. Rio de Janeiro: Rio Books; PROURB.

Araújo, J. de L. O., Araújo, A. C., \& Araújo, A. C. (2010). Percepção ambiental dos residentes do bairro Presidente Médici em Campina Grande, PB, no tocante à arborização local. REVSBAU, 3, 1-14.

Brasil (2004). Decreto Federal 5296 de 2 de dezembro de 2004. Regulamenta as Leis ${ }^{\circ} 10.048$, de 8 de novembro de 2000, que dá prioridade ao atendimento às pessoas que especifica, e 10.098, de 19 de dezembro de 2000, que estabelece normas gerais e critérios básicos para promoção da acessibilidade das pessoas portadoras de deficiência ou com mobilidade reduzida, e dá outras providências. Recuperado de < http://portal.mec.gov.br/seesp/arquivos/pdf/decreto\%205296-2004.pdf> .

Cicea, C., \& Pirlogea, C. (2011). Green spaces and public heath in urban areas. Revista Theoretical and Empirical Researches in Urban Management, 6 (1). 
Chomistek, A. K. et al. (2013). Physical activity, genes for physical fitness, and risk of coronary heart disease. Medicine and Science in Sports and Exercise, 45 (4) pp. 691-697.

Cormier, N. S., \& Pellegrino, P. R. M. (2008). Infra-estrutura Verde: uma estratégia paisagística para a água urbana. Paisagem Ambiente: Ensaios, (25), 127-142.

Costa, R. G. S., \& Colesanti, M. M.(2011). A contribuição da percepção ambiental nos estudos das áreas verdes (pp. 238-251). Curitiba: RA'E GA. Departamento de Geografia.

Costa, M. T. (2011) A Importância das áreas verdes para a qualidade ambiental das cidades. Revista Formação, 13, pp. 139-165.

Edmondson, J. L. et al. (2016) Soil surface temperatures reveal moderation of the urban heat island effect by trees and shrubs. Scientific Reports, 2016, 6, Nature Publishing Group.

Gartland, L. (2001). Cool roof energy savings evaluation for City of Tucson Thomas. O.Price Service Center Administration Building One, 94609 (510).

Gartland, L. (2010). Ilhas de Calor: Como Mitigar Zonas de Calor em Áreas Urbanas, 248. Recuperado de: https://books.google.com/books?id=a8YbSgAACAAJ\&pgis=1

Gil, A. C. (1999). Métodos e Técnicas de Pesquisa Social (5a. ed.). São Paulo: Atlas.

Gülten, A., Aksoy, U. T., \& Öztop, H. F. (2016). Influence of trees on heat island potential in an urban canyon. Sustainable Cities and Society, 26, pp.407-418.

Herzog, C. P. (2010). Infra-estrutura verde para cidades mais sustentáveis. Seção IV Ambiente construído. Secretaria do Ambiente do Rio de Janeiro.

Kubota, Y. et al. (2017). Physical Activity and Lifetime Risk of Cardiovascular Disease and Cancer. Medicine \& Science in Sports \& Exercise, p. 1.

Livesley, S. J., Mcpherson, G. M., \& Calfapietra, C. (2016). The Urban Forest and Ecosystem Services: Impacts on Urban Water, Heat, and Pollution Cycles at the Tree, Street, and City Scale. Journal of environmental quality, 45 (1), pp.119-24. January.

Lopes, A. (2006). 0 sobreaquecimento das cidades: causas e medidas para a mitigação da ilha de calor de Lisboa. In: $6^{\circ}$ Jornada de Climatização da Ordem dos Engenheiros (pp. 39-52).

Marques, T. H. N., \& Batistela, T. S. (2016). Percepção da caminhabilidade no entorno da interseção das avenidas Engenheiro Caetano Álvares e Imirim. Revista LabVerde, 12, 151-177.

Maruyama, C., \& Franco, M. de A. R. (2016). Pavimentos permeáveis e infraestrutura verde. Periódico Técnico E Científico Cidades Verdes, 4(9), 73-86. Recuperado de: https://doi.org/10.17271/231786044920161384

Mascaró, L., \& Mascaró, J. (2005). Vegetação Urbana (2a. ed.). Porto Alegre: Editores L e J Mascaró.

Mascaró, J. L. (2005). Loteamentos Urbanos (2a. ed.). Porto Alegre: Masquatro Editora.

Matsudo, S. M., Matsudo, V. R., Araújo, T., Andrade, D., Andrade, E., \& Oliveira, L. (2002). Nível de atividade física da população do Estado de São Paulo: análise de acordo com o gênero , idade , nível socioeconômico , distribuição geográfica e de conhecimento. Revista Brasileira de Ciência E Movimento, 10 (4), 2002.

Moura, N. C. B. de. (2013). Biorretenção tecnologia ambiental urbana para o manejo das águas da chuva. Universidade de São Paulo.

Nucci, J. C. (2008). Qualidade ambiental e adensamento urbano. Um estudo de Ecologia e Planejamento da Paisagem aplicado ao distrito de Santa Cecília (2a.ed.) (MSP): Curitiba, 150p. 
Oliveira, C.H. (1996). Planejamento ambiental na Cidade de São Carlos (SP) com ênfase nas áreas públicas e áreas verdes: diagnóstico e propostas. Dissertação de Mestrado, Universidade Federal de São Carlos, São Carlos, SP, Brasil.

Pisello, A. L. (2017). State of the art on the development of cool coatings for buildings and cities. Solar Energy, 144, 660-680. Recuperado de: https://doi.org/10.1016/j.solener.2017.01.068

Portland (2016). Stormwater Management Manual. Recuperado de: <https://www.portlandoregon.gov/ bes/64040>.

Prinz, D. (1980). Urbanismo I. Projecto Urbano. Lisboa: Editorial Presença.

Qin, Y., \& Hiller, J. E. (2016). Water availability near the surface dominates the evaporation of pervious concrete. Construction and Building Materials, 111, 77-84. Recuperado de: https://doi.org/10.1016/ j.conbuildmat.2016.02.063 .

Rodrigues, T. D., Malafaia, G., Queiroz, S. É. E., \& Rodrigues, A. S. de L. (2010). Percepção sobre arborização urbana de moradores em três áreas de Pires do Rio - Goiás. Revista de Estudos Ambientais, 12(2), 47-61.

Rosenfeld, A. H., Akbari, H., Romm, J. J., \& Pomerantz, M. (1998). Cool communities: strategies for heat island mitigation and smog reduction. Energy and Buildings, 28(1), 51-62. Recuperado de: https://doi.org/ 10.1016/S0378-7788(97)00063-7 .

Santos, G. E. O. (sem data). Cálculo amostral: calculadora on-line.

Recuperado de: <http://www.calculoamostral.vai.la $>$.

São Paulo (município). (2005). Decreto $n^{\circ} 45.904$ de 19 de maio de 2005. Regulamenta o artigo $6^{\circ}$ da Lei $n^{\circ}$ 13.885 de 25 de agosto de 2004, no que se refere à padronização dos passeios públicos do Município de São Paulo. Recupeado de: <http://www3.prefeitura.sp.gov.br/cadlem/secretarias/negocios_juridicos/cadlem/ integra.asp?alt $=20052005 \mathrm{D} \% 20459040000>$.

São Paulo/SP (sem data). Prefeitura. Secretaria do Verde e do Meio Ambiente - Atlas Ambiental do Município de São Paulo. Temperatura de Superfície. Recuperado de: <http://atlasambiental.prefeitura.sp.gov.br/conteudo/ clima_urbano/clima_temp_09.htm>.

Schützer, K. (2011). A Percepção do Pedestre Sobre a Qualidade da Paisagem Urbana. Disseratação de Mestrado, Universidade Federal de São Carlos, Programa de pós-graduação em Engenharia Urbana, São Carlos, SP, Brasil. 